Article

\title{
Mechanical Properties of Hybrid Ultra-High Performance Engineered Cementitous Composites Incorporating Steel and Polyethylene Fibers
}

\author{
Yingwu Zhou ${ }^{1}$, Bin $\mathrm{Xi}^{1}{ }^{1}$, Kequan Yu ${ }^{2}$, Lili Sui ${ }^{1}$ and Feng Xing ${ }^{1, *}$ \\ 1 Guangdong Provincial Key Laboratory of Durability for Marine Civil Engineering, Shenzhen University, \\ Shenzhen 518060, China; ywzhou@szu.edu.cn (Y.Z.); 2170338112@email.szu.edu.cn (B.X.); \\ suill8969@163.com (L.S.) \\ 2 The Hong Kong Polytechnic University, Hong Kong; zjzjykq@163.com \\ * Correspondence: xingf@szu.edu.cn
}

Received: 31 July 2018; Accepted: 13 August 2018; Published: 16 August 2018

\begin{abstract}
This paper presents the authors' newly developed hybrid ultra-high performance (HUHP) engineered cementitious composite (ECC) with steel (ST) and polyethylene (PE) fibers. From this point on it will be referred to as HUHP-ECC. The volumes of steel and PE fibers were adjusted to obtain different mechanical properties, including compressive strength, tensile, and flexural properties. We found that tensile and flexural properties, including bending strength and ductility indexes, increased with higher PE fiber amounts but reduced with the increased ST fiber volume. Notably, the compressive strength had the opposite tendency and decreased with increases in the PE volume. The ST fiber had a significantly positive effect on the compressive strength. The fluidity of HUHP-ECC improved with the increasing amount of ST fiber. The pseudo strain-hardening (PSH) values for all the HUHP-ECC mixtures were used to create an index indicating the ability of strain capacity; thus, the PSH values were calculated to explain the ductility of HUHP-ECC with different fiber volumes. Finally, the morphology of PE and ST fibers at the fracture surface was observed by an environmental scanning electron microscope (ESEM).
\end{abstract}

Keywords: ultra-high performance engineered cementitious composites; steel fiber; polyethylene fiber; high strength; high ductility

\section{Introduction}

The engineered cementitious composite (ECC) was designed based on the micromechanics theory [1-3] and featured with the strain-hardening behavior. The conventional polyvinyl alcohol fiber (PVA) ECC has a tensile strain capacity of more than $3 \%$ and a maximum tensile strength between 3 and $6 \mathrm{MPa}$, with a fiber volume fraction of no more than $2 \%$ [4-6]. The tensile strain capacity of ECC is about 300 to 500 times larger than that of normal concrete [1,3]. In addition, ECC exhibits multiple cracking during strain-hardening process with a micro-crack width of less than $100 \mu \mathrm{m}$ [7], making it a highly durable material in a wide variety of environmental exposure conditions. Recently, researchers (including the authors) used ultra-high molecular weight polyethylene fiber (UHMWPE or PE for short) to develop ultra-high performance engineered cementitious composites (UHP-ECC) [8-11]. Its compressive strength, tensile strength, and tensile strain capacity can reach $120-150 \mathrm{MPa}, 15-20 \mathrm{MPa}$, and $8 \%$, respectively $[10,11]$. The UHP-ECC already has vast development prospects in all kinds of civil engineering applications.

Nevertheless, the fiber aspect ratio of PE fiber, i.e., the fiber length to diameter $\left(L_{\mathrm{f}} / d_{\mathrm{f}}\right)$ was always higher than 500, which imposed a significantly negative impact of fluidity of mortar and led to the uneven fiber dispersion and the instability of tensile performance of the UHP-ECC specimen [9-13]. 
The low fluidity of UHP-ECC also caused considerable difficulty in construction. Additionally, the melting point of $\mathrm{PE}$ fiber is only $130-150{ }^{\circ} \mathrm{C}$, which has led to a notable reduction in the tensile performance of UHP-ECC as the temperature increases [14-17]. Therefore, how to improve the workability and fire resistance of UHP-ECC needs to be urgently addressed.

Recently, the ultra-high performance concrete (UHPC) known for its high compressive strength and high fluidity of mortar has attracted wide attention [18-20]. To ensure a highly dense matrix, fine powders, such as quartz flour, silica fume, and glass powder were used in the mixture and steel (ST) fibers (1-6\% (by volume)) were also added to enhance the compressive performance and fracture toughness [18-22]. The compressive strength of UHPC is usually greater than $150 \mathrm{MPa}$, and it has excellent fire resistance and workability [21-26]. However, the steel fiber reinforced UHPC always has experiences a tension-softening property after peak stress or a low strain-hardening property with a tensile capacity of about $0.6 \%$ due to the relatively lower fiber aspect ratio of steel fibers [27-31] and the maximum limit in steel fiber volume, which is more than 10 times lower than that of UHP-ECC.

Therefore, some researchers have [32-37] tried to combine reinforced cementitious composite material with two or more different fibers to improve the above concerned properties by creating a hybrid (the engineered cementitious composite). Ahmed and Maalej [37] investigated the tensile mechanical behavior of ECC hybrids reinforced with PE and ST fibers. They observed that the hybrid fiber-reinforced ECC material showed a higher tensile strain capacity than the reinforced HUHP-ECC with mono ST fibers, and a significant improvement in tensile strength compared with ECC reinforced with mono PE fibers. However, the tensile strain capacity of hybrid fiber-reinforced ECC was 3-5\% and the maximum tensile strength was within $5 \mathrm{MPa}$. Both parameters represent a significant increase in functionality, which motivated further investigation into the mechanical properties of UHP-ECC hybrid concrete reinforced with ST and PE fibers.

The authors developed a UHP-ECC reinforced with hybrid ST and PE fiber (HUHP-ECC) concrete with both UHP-ECC and UHPC advantages. HUHP-ECC had good workability, tensile and flexural strain-hardening performance, as well as excellent compressive strength. Based on the design criteria of ECC [38,39], different mechanical properties, including the compressive strength, tensile, and flexural properties of HUHP-ECC, were obtained by adjusting the volume fraction of ST and PE fiber. Moreover, we were able to establish the relationships of mechanical properties and fiber content. Finally, the morphology of PE, ST fiber, and matrix was observed by using environmental scanning electron microscopy (ESEM).

\section{Experimental Program}

\subsection{Materials and Mix Proportions}

The raw materials of the HUHP-ECC binder were ordinary Portland cement 52.5R (OPC) from China Resources Cement Holdings Limited, Foshan, China, ground granulated blast furnace slag (GGBFS) and silica fume (SF). Pozzolanic materials like GGBFS and SF were incorporated to promote the formation of the secondary hydration products (calcium silicate hydrate). In addition, a polycarboxylate-based high-range water-reducing admixture (HRWRA) from Sika Co. Ltd (Sika China Group, Guangzhou, China) was used in HUHP-ECC to maintain the fluidity of the mixture at a very low water/binder ratio. Fine silica sand with a maximum grain size of $300 \mu \mathrm{m}$ and a mean size of $100 \mu \mathrm{m}$ was utilized as the fine aggregate. Figure 1 shows that the fine particle sizes from small to large successively are SF ( 0 to $1 \mu \mathrm{m})$, GGBFS (1 to $30 \mu \mathrm{m}$ ), OPC (2 to $300 \mu \mathrm{m})$ and silica sand (50 to $300 \mu \mathrm{m})$. The chemical compositions and the physical and mechanical properties of the cementitious materials including OPC, SF and GGBFS are listed in Table 1.

Table 2 presents the properties of steel (ST) fiber and polyethylene (PE) fiber. Both fibers have tensile strength larger than $2700 \mathrm{MPa}$. The steel fibers used in this study were straight and with a circular cross-section. The fiber aspect ratio (fiber length to diameter ratio, $L_{f} / d_{f}$ ) of PE is 720 and is much larger than that of steel fiber (65), which would cause tensile properties to have different 
effects. In addition, the different elastic moduli of the two fibers would also affect the compressive performances. The total volume fraction of steel fiber and PE fibers was kept at $2 \%$. The mixtures were named as HUHP-ECC-A-B, where A meant the PE fiber content, and B meant the steel fiber content. A total of five mixtures were set with both PE fiber and ST fiber ranging from $2.0 \%$ to $0 \%$ with an interval of $0.5 \%$. Take for example the HUHP-ECC-1.5-0.5, it means the HUHP-ECC specimen contains $1.5 \%$ of PE fiber and $0.5 \%$ ST fiber. Detailed mix proportions of HUHP-ECCs are listed in Table 3.

Table 1. Chemical properties of cement, silica fume, and ground granulated blast furnace slag (GGBFS).

\begin{tabular}{ccccc}
\hline & Ingredients & OPC & GGBFS & SF \\
\cline { 2 - 5 } & $\mathrm{Na}_{2} \mathrm{O}$ & 0.08 & 0.20 & 0.42 \\
& $\mathrm{MgO}$ & 0.66 & 6.94 & 0.96 \\
& $\mathrm{Al}_{2} \mathrm{O}_{3}$ & 4.42 & 12.94 & 0.89 \\
$\mathrm{SiO}_{2}$ & 19.9 & 39.66 & 92.26 \\
Chemical Composition (\%) & $\mathrm{P}_{2} \mathrm{O}_{5}$ & 0.10 & $/$ & $/$ \\
& $\mathrm{SO}_{3}$ & 2.67 & 0.72 & 0.33 \\
& $\mathrm{~K}_{2} \mathrm{O}$ & 0.79 & 1.44 & 1.31 \\
$\mathrm{CaO}$ & 64.9 & 34.20 & 0.49 \\
& $\mathrm{TiO}_{2}$ & 0.21 & $/$ & $/$ \\
$\mathrm{MnO}$ & 0.10 & $/$ & $/$ \\
& $\mathrm{Fe}_{2} \mathrm{O}_{3}$ & 3.00 & 1.58 & 1.97 \\
\hline
\end{tabular}

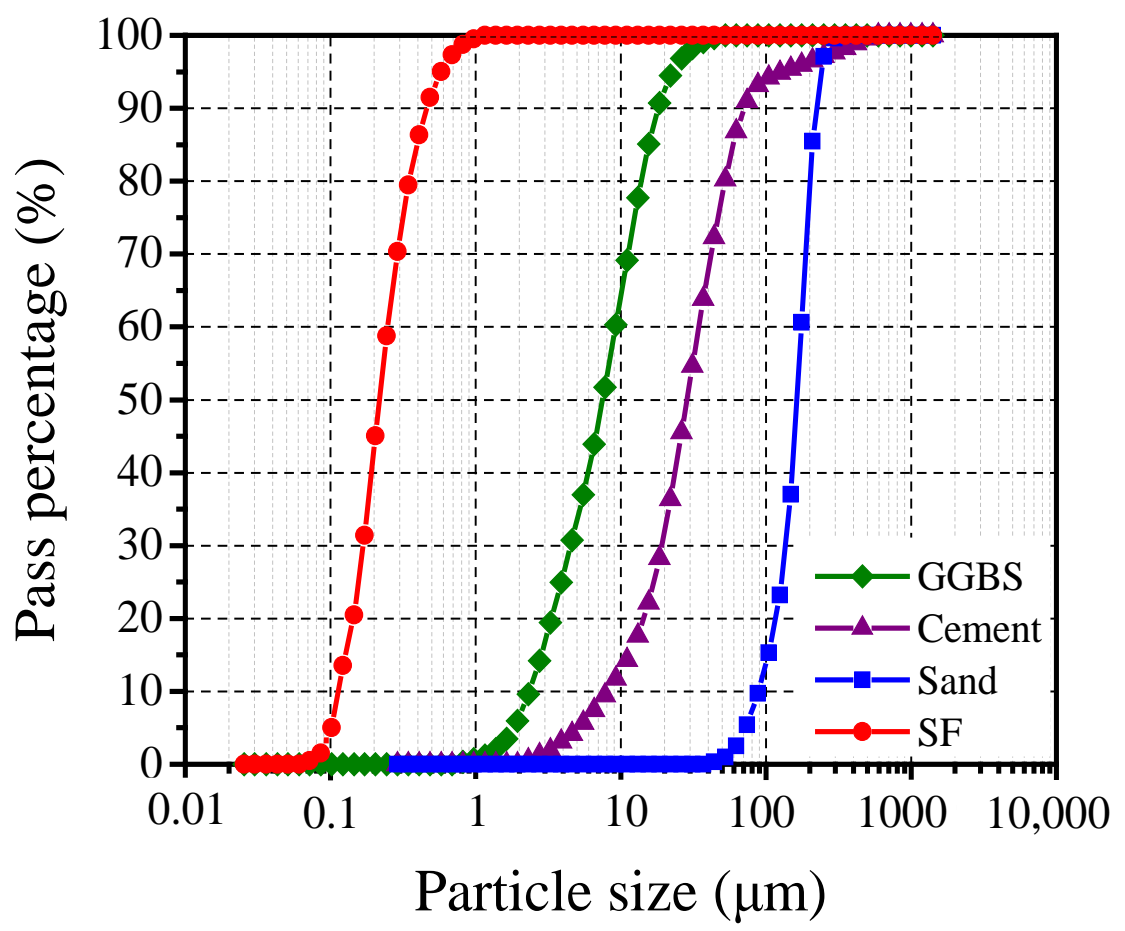

Figure 1. Particle size distributions of the component. 
Table 2. Properties of fibers.

\begin{tabular}{|c|c|c|c|c|c|c|c|c|c|c|}
\hline Fiber Types & Length (mm) & \multicolumn{2}{|c|}{ Diameter $(\mu \mathrm{m})$} & \multicolumn{2}{|c|}{ Fiber Aspect Ratio $L_{f} / d_{f}$} & \multicolumn{3}{|c|}{ Modulus of Elasticity (GPa) } & Fiber Strength (MPa) & Fiber D \\
\hline Straight Steel & 13 & \multicolumn{2}{|c|}{200} & \multicolumn{2}{|c|}{65} & \multicolumn{3}{|c|}{200} & 2750 & \\
\hline PE & 18 & \multicolumn{2}{|c|}{25} & \multicolumn{2}{|r|}{750} & \multicolumn{3}{|c|}{116} & 2900 & \\
\hline & \multicolumn{10}{|c|}{ Table 3. Mixture proportion $\left(\mathrm{kg} / \mathrm{m}^{3}\right)$. } \\
\hline & \multirow{2}{*}{\multicolumn{2}{|c|}{ Mixture ID }} & \multirow{2}{*}{ Cement } & \multirow{2}{*}{ SF } & \multirow{2}{*}{ GGBFS } & \multirow{2}{*}{ Sand } & \multirow{2}{*}{ Water } & \multicolumn{2}{|c|}{ Fiber volume fraction $(\%)$} & \multirow{2}{*}{ HRWRA } \\
\hline & & & & & & & & PE & ST & \\
\hline & \multicolumn{2}{|c|}{ HUHP-ECC-2.0-0 } & 700 & 230 & 750 & 500 & 230 & 2.0 & 0 & 45 \\
\hline & \multicolumn{2}{|c|}{ HUHP-ECC-1.5-0.5 } & 700 & 230 & 750 & 500 & 230 & 1.5 & 0.5 & 45 \\
\hline & \multicolumn{2}{|c|}{ HUHP-ECC-1.0-1.0 } & 700 & 230 & 750 & 500 & 230 & 1.0 & 1.0 & 45 \\
\hline & \multicolumn{2}{|c|}{ HUHP-ECC-0.5-1.5 } & 700 & 230 & 750 & 500 & 230 & 0.5 & 1.5 & 45 \\
\hline & \multicolumn{2}{|c|}{ HUHP-ECC-0-2.0 } & 700 & 230 & 750 & 500 & 230 & 0 & 2.0 & 45 \\
\hline
\end{tabular}




\subsection{Mixing Procedure}

All the mixtures were made in a vertical axis and speed adjustable mixer. First, dry powders and aggregates were mixed for about $2 \mathrm{~min}$. The mixing speed was set at $140 \mathrm{rpm}$ for $3 \mathrm{~min}$ after the addition of water (with HRWRA) and then set at $420 \mathrm{rpm}$ for another $2 \mathrm{~min}$. ST fibers were first added; then, the PE fibers were added in two batches to obtain better fiber dispersion. Before casting, the spread fluidity value of all the mixtures was measured according to the standard GBT 2419-2005 [40]. The specimens were kept in the mold for $24 \mathrm{~h}$ at room temperature. After demolding, all the specimens were cured in a curing room with a temperature of $23 \pm 3{ }^{\circ} \mathrm{C}$ and humidity of $95 \%$ for 28 days.

\subsection{Test Specimens and Test Setups}

The experimental investigations, including the four-point bending tests and the uniaxial tension/compression tests, were implemented in the present study. In addition, the matrix fracture toughness test and the single crack tension test were conducted as well to obtain the matrix fracture energy $J_{\text {tip }}$ and fiber bridging complementary energy $J_{\mathrm{b}}{ }^{\prime}$, respectively. Table 4 lists the corresponding specimen numbers for each mix proportion.

The dogbone-shaped specimen shown in Figure 2 was cast as per the Japan Society of Civil Engineers (JSCE) [41] to carry out a uniaxial tension test. All the specimens were loaded with the MTS Landmark electro-hydraulic servo machine under displacement control at a loading rate of $1 \mathrm{~mm} / \mathrm{min}$. To determine each specimen's tensile stress-strain relationship, two linear variable displacement transducers (LVDTs) were fixed on each side of each dogbone specimen with a gauge length of $80 \mathrm{~mm}$, as shown in Figure 2. Additionally, 6 cubes $\left(40 \times 40 \times 40 \mathrm{~mm}^{3}\right)$ representing each mixture were tested to obtain the compressive strength.

To obtain the flexural properties, four-point bending tests were performed on HUHP-ECC $40 \times 40 \times 160 \mathrm{~mm}^{3}$ beams at a loading rate of $1 \mathrm{~mm} / \mathrm{min}$ according to CECS (2009) [42]. The deflections at the support and midspan points were traced by two LVDTs (see Figure 3). The real mid-span deflection was then calculated by subtracting the value of the LVDTs at the mid-span point by the average displacement of the two supports.

To figure out the influence of matrix toughness on the tensile ductility of HUHP-ECCs, the three-point bending tests of the HUHP-ECCs matrix (without fiber) were conducted on $40 \times 40 \times 160 \mathrm{~mm}^{3}$ notched beams following the RILEM method [43] to calculate the matrix toughness of each HUHP-ECC specimen (Figure 4). Therefore, beams were cast in accordance with the mixture proportion but without adding the fibers as listed in Table 2. The initial notch/beam depth ratio was 0.3. Before testing, a notch $12 \mathrm{~mm}$ in depth was cut on the bottom surface at the midspan by using an electrical diamond saw. MTS Landmark electro-hydraulic servo machine was employed in the bending tests and the ultimate loads were recorded.

The single-crack tensile tests were carried out to obtain the bridging stress $(\sigma)$-crack opening $(\delta)$ relation $(\sigma-\delta$ curve) of HUHP-ECCs. Dogbone specimens were notched on four faces to facilitate the formation of a single crack (see Figure 5). An ultra-thin saw blade ( $0.4 \mathrm{~mm}$ in thickness) was used to cut a notch with a width less than $0.6 \mathrm{~mm}$. Figure $5 \mathrm{~b}$ shows the geometric dimension of the notched cross section of the single-crack specimen. To keep an extra crack from occurring inside or outside the notch, the adopted dimensions allowed a $61 \%$ reduction of the cross-section's initial value. Ideally, a single crack should occur at the notch when the tensile load is applied. Two clip-on gauges with a uniform gauge length of $5 \mathrm{~mm}$ measured the crack opening in the test as shown in Figure 5a. 
Table 4. Numbers of replicate specimens in each test.

\begin{tabular}{cccccc}
\hline Mixture ID & $\begin{array}{c}\text { HUHP- } \\
\text { ECC-2.0-0 }\end{array}$ & $\begin{array}{c}\text { HUHP- } \\
\text { ECC-1.5-0.5 }\end{array}$ & $\begin{array}{c}\text { HUHP- } \\
\text { ECC-1.0-1.0 }\end{array}$ & $\begin{array}{c}\text { HUHP- } \\
\text { ECC-0.5-1.5 }\end{array}$ & $\begin{array}{c}\text { HUHP- } \\
\text { ECC-0-2.0 }\end{array}$ \\
\hline Uniaxial Tension Test & 8 & 8 & 8 & 8 & 8 \\
Uniaxial Compression Test (cube) & 6 & 6 & 6 & 6 & 6 \\
Four-Point Flexural Test & 6 & 6 & 6 & 6 & 6 \\
Single Crack Tension Test & 8 & 8 & 8 & 8 & 8 \\
\hline
\end{tabular}

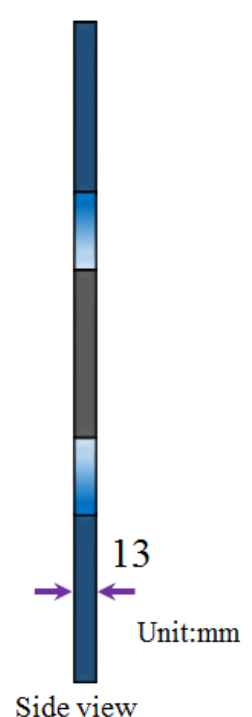

Side view

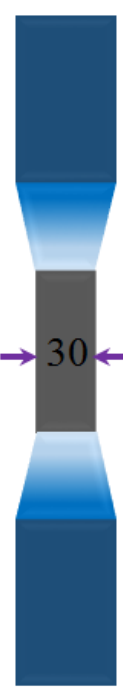

Plain view

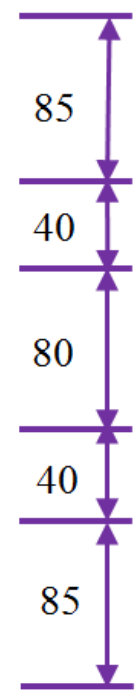

(a)

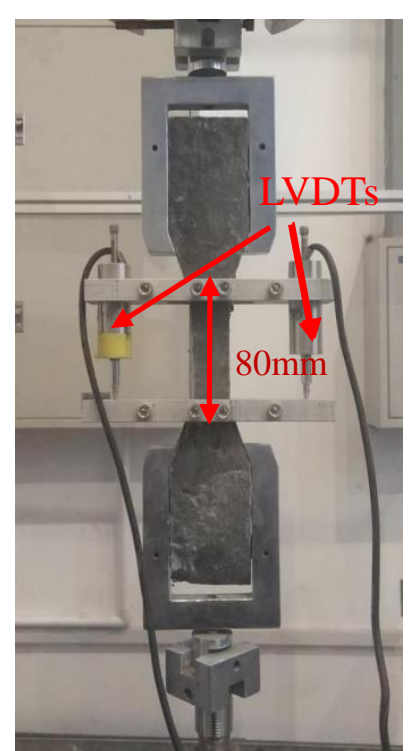

(b)

Figure 2. Dogbone specimen for engineered cementitious composite (ECC) tensile test. (a) Dimension of dog bone specimen; (b) Test setup.

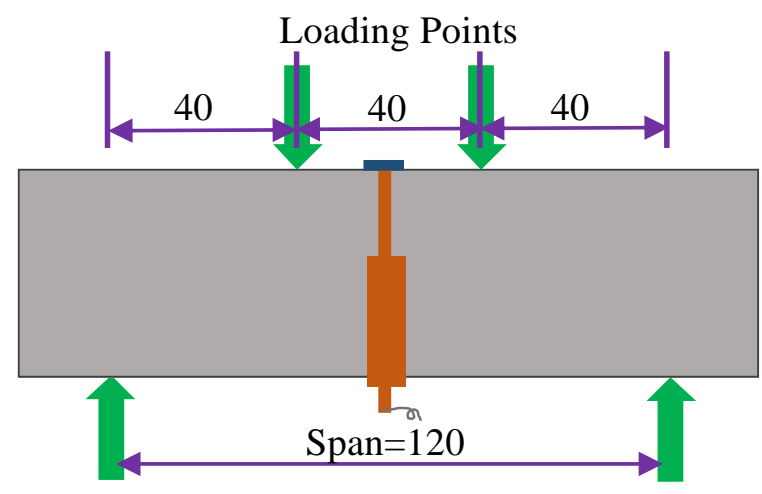

(a)

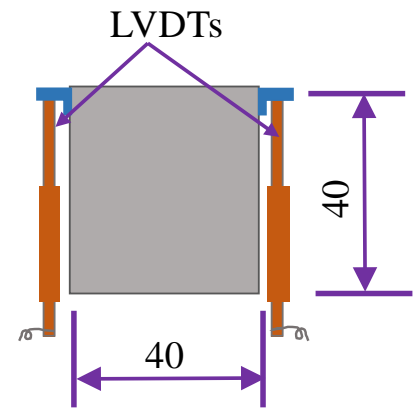

(b)

Figure 3. Specimen dimensions and test set up for bending test (Unit: mm). (a) Front elevation; (b) Transverse section. 


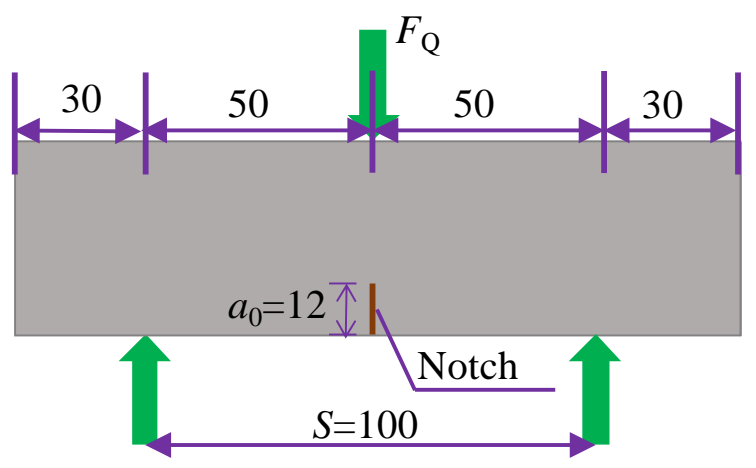

(a)

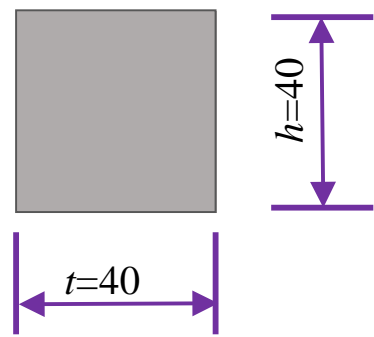

(b)

Figure 4. Specimen dimensions and test set up for matrix toughness test (Unit: mm). (a) Front elevation; (b) Transverse section.

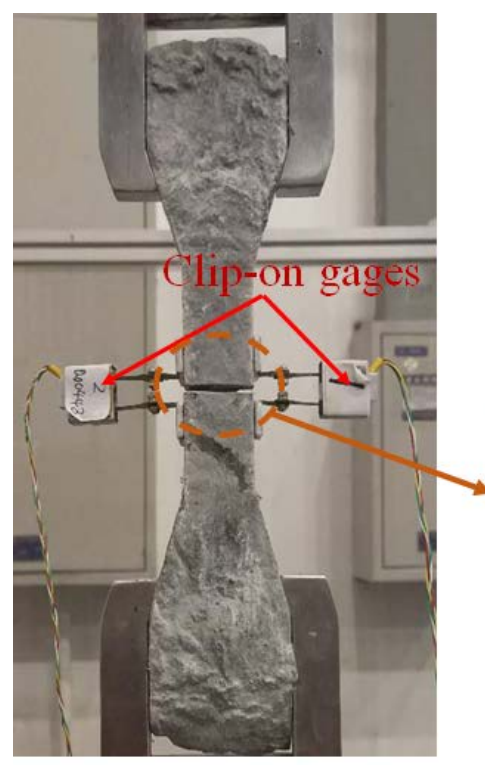

(a)

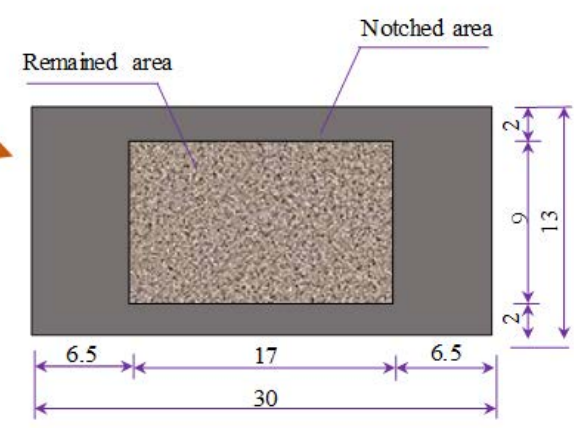

(b)

Figure 5. Single-crack tension test. (a) Instrumentation and (b) Notched dogbone specimen (unit: $\mathrm{mm}$ ).

\section{Results and Discussion.}

\subsection{Tests of the Spread Fluidity}

The flow behavior of concrete governs its mechanical properties. The spread fluidity value is used to evaluate the flow behavior of concrete according to the standard GBT 2419-2005 [40]. Figure 6 presents the results of the spread fluidity tests for the freshly-mixed HUHP-ECCs pastes. The spread fluidity value increased significantly with the increasing amount of steel fiber because the ST fiber number and specific surface area is smaller than the PE fiber under the same volume fraction. The spread fluidity value was $140 \mathrm{~mm}$ for HUHP-ECC-2.0-0 with $2 \%$ PE fiber and $330 \mathrm{~mm}$ for HUHP-ECC-0-2.0 with $2 \%$ ST fiber. When the steel fiber volume fraction ranged from $0.5 \%$ to $1.5 \%$, the spread fluidity value of HUHP-ECCs increased from 170 to $270 \mathrm{~mm}$, which shows the introduction of ST fiber can result in a better workability. 


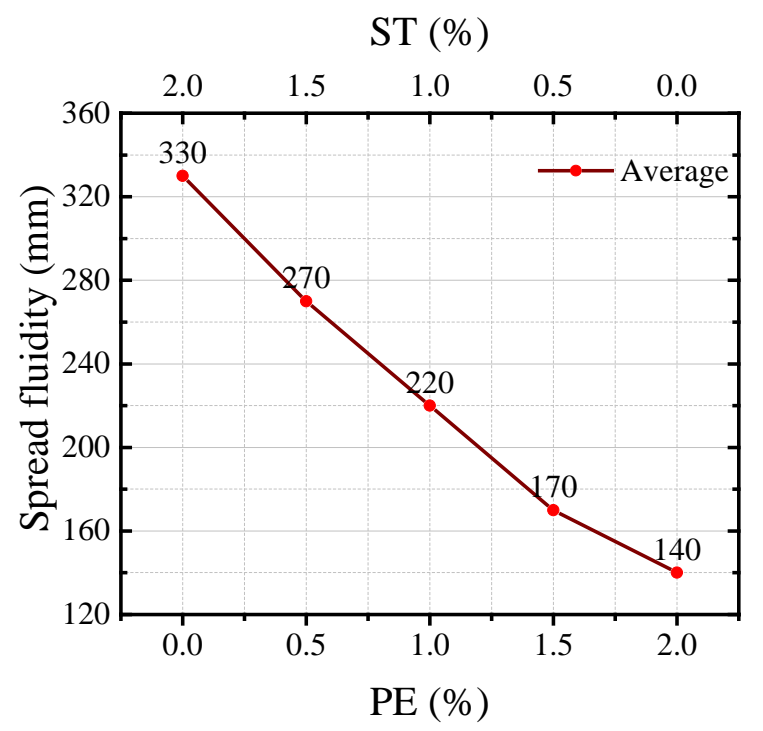

Figure 6. Spread fluidity of the freshly-mixed pastes of hybrid ultra-high performance (HUHP)-ECCs.

\subsection{Tensile Properties}

\subsubsection{Tensile Stress-Strain of HUHP-ECCs}

Figure 7 describes the uniaxial tensile stress-strain curves of HUHP-ECCs. All the mixtures demonstrated the strain-hardening phenomenon except for the UHP-ECC-0-2.0 with 2\% ST fiber, which showed a general tension-softening behavior (see Figure 7e). Figure $7 f$ shows that PE fiber has a decisive influence on strain-hardening and tensile properties, including the tensile strength and strain capacity, both of which increased with the amount of PE fiber. The HUHP-ECC-2.0-0 with mono PE fiber reached the maximum tensile strength of around $15.5 \mathrm{MPa}$ and a maximum tensile strain capacity of up to $9 \%$, while the HUHP-ECC-0-2.0 with mono ST fiber showed a general strain-softening property and the tensile strength was only around $8.5 \mathrm{MPa}$. This is because the ST fiber had much lower fiber aspect ratio $L_{f} / d_{f}(65)$ than that of PE fiber in the present research (750) and was long straight fiber with smooth surface which presented poor tensile strain capacity compared with that of hooked or twisted fiber due to the lower interfacial bond stress [32]. Notably, with $0.5 \%$ and $1.0 \%$ PE fiber, both the HUHP-ECC-0.5-1.5 and HUHP-ECC-1.0-1.0 showed a tensile strain of around 2\% and a tensile strength of $9.9 \mathrm{MPa}$. Additionally, the HUHP-ECC-1.5-0.5 showed a prominent strain-hardening behavior with a strain capacity of $8 \%$ and tensile strength of approximately $12.4 \mathrm{MPa}$. Considering the better fluidity of these three mixtures, the hybrid UHP-ECCs provided alternatives for structural application.

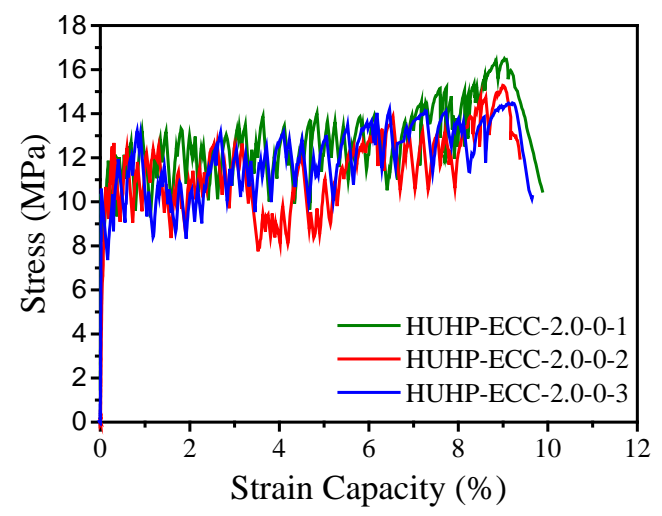

(a)

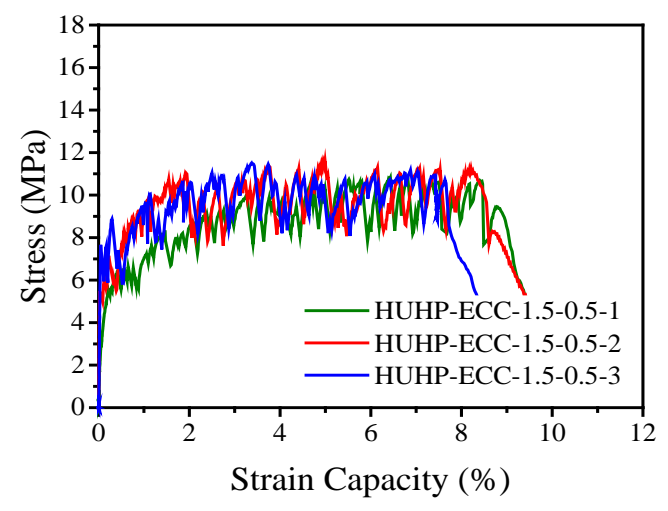

(b)

Figure 7. Cont. 


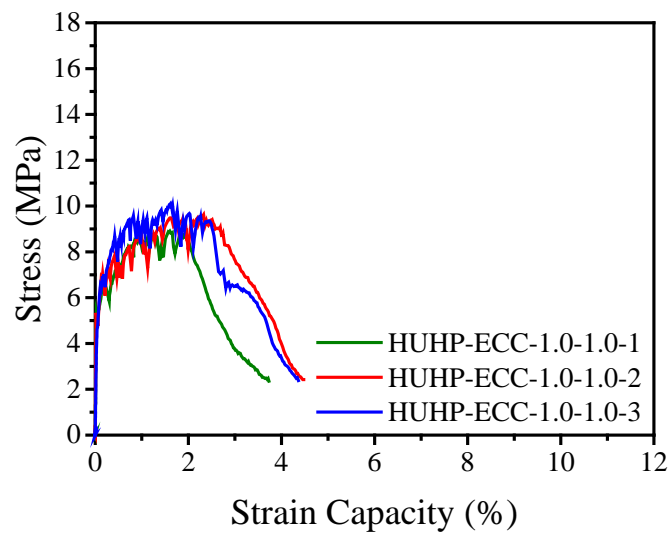

(c)

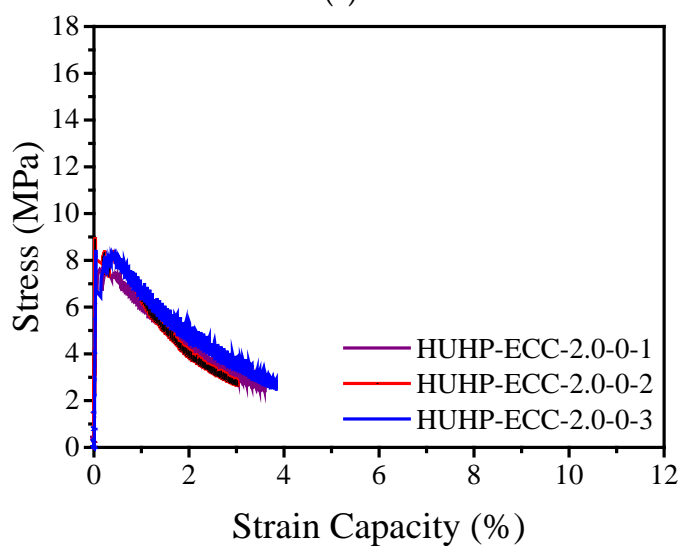

(e)

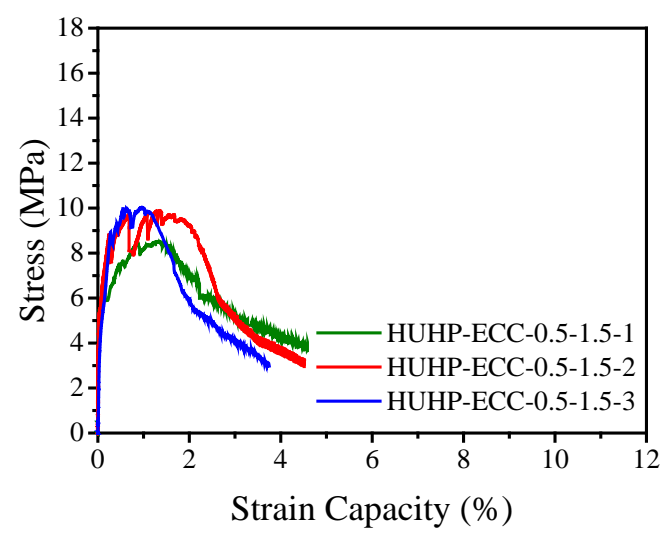

(d)

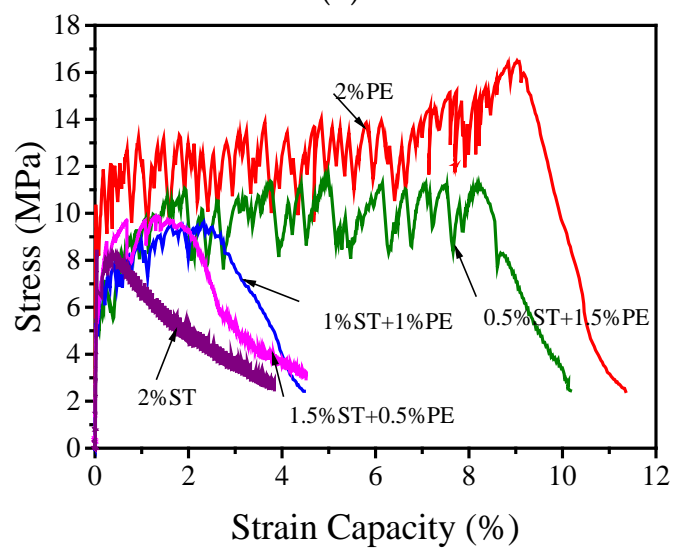

(f)

Figure 7. Tensile stress-strain curves of HUHP-ECCs. (a) HUHP-ECC-2.0-0; (b) HUHP-ECC-1.5-0.5; (c) HUHP-ECC-1.0-1.0; (d) HUHP-ECC-0.5-1.5; (e) HUHP-ECC-0-2.0; (f) Stress strain capacity of different volume fractions of PE and ST fibers.

\subsubsection{Tensile Parameters of HUHP-ECCs}

Figure 7 shows that the stress-strain relationship of HUHP-ECCs incorporating with different amount of ST and PE fibers feature a bilinear behavior as summarized in Figure 8, where $\sigma_{\text {tc }}$ and $\sigma_{\text {tu }}$ are the initial cracking strength and the peak stress, respectively. $\varepsilon_{\mathrm{tu}}$ is the strain capacity corresponding to the peak stress, and $g_{\text {se }}$ is the energy absorption capacity which equates to the area enclosed with the bilinear curve.

The initial cracking stress $\sigma_{\text {tc }}$ represents the turning point from the linear elastic portion to the strain hardening portion of the stress-strain curves. The value of the initial cracking stress $\sigma_{\text {tc }}$ was determined from the beginning point of the strain hardening branch of the stress-strain curves. The strain energy $g_{\text {se }}$ was calculated using the area underneath the ascending branch of stress-strain curves. The descending branch of the stress-stain curves during the crack localization stage was not considered in this calculation.

Based on Figures 7 and 8, the tensile parameters of HUHP-ECCs, including the initial cracking stress, tensile strength, tensile strain capacity, and strain energy, were thus obtained and their relationship with the amount of ST or PE fibers are showed in Figure 9. It could be seen that these parameters increased significantly with the amount of PE fiber due to the much higher fiber aspect ratio of the PE fiber compared to that of the steel fiber. The average initial cracking stress increased from 8.4MPa of HUHP-ECC-0-2.0 (mono ST fiber) to 12.5 MPa of HUHP-ECC-2.0-0 (mono PE fiber). The average tensile strength of HUHP-ECC-0-2.0 was $8.5 \mathrm{MPa}$ and first increased steadily to 9.9 MPa of HUHP-ECC-1.0-1.0; then to 11.3 MPa of HUHP-ECC-0.5-1.5, and finally to $15.5 \mathrm{MPa}$ of 
HUHP-ECC-2.0-0 with an increase of $182 \%$. The average tensile strain capacity increased from $0.41 \%$ of HUHP-ECC-0-2.0 (corresponding to the onset of descending branch) to 9.1\% of HUHP-ECC-2.0-0 with an increase of 23 times, which showed the decisive influence of PE fiber on the tensile strain capacity. Notably, a sudden drop occurred of strain capacity from HUHP-ECC-1.5-0.5 (8.1\%) to HUHP-ECC-1.0-1.0 (2.2\%), which may be attributed to the disturbance of steel fiber to the dispersion of PE fiber as the volume fraction of the PE fiber approached the critical fiber volume that could maintain the strain-hardening performance [3,4]. Additionally, the strain capacity of HUHP-ECC-1.5-0.5 and HUHP-ECC-1.0-1.0 were $2.2 \%$ and $1.6 \%$, respectively, which was still three to four times higher than the value of UHPC $[27,28]$. This increased strain capacity ensures a better interaction between HUHP-ECC and steel bars at the post-yielding stage. The average strain energy shared a similar tendency with strain capacity and increased from $1.3 \mathrm{~kJ} / \mathrm{m}^{3}$ of HUHP-ECC-0-2.0 to $1094.2 \mathrm{~kJ} / \mathrm{m}^{3}$ of HUHP-ECC-2.0-0. The strain energies of the other three hybrid fiber reinforced UHP-ECCs are $93.6,138.4$ and $700.4 \mathrm{~kJ} / \mathrm{m}^{3}$, respectively. The high strain energy would facilitate the application of HUHP-ECCs in the seismic area for energy absorption. The improvement in tensile performance of HUHP-ECCs with the increased amount of PE fiber was attributed to the larger values of the PSH index in these cases, which will be analyzed in Section 3.5.

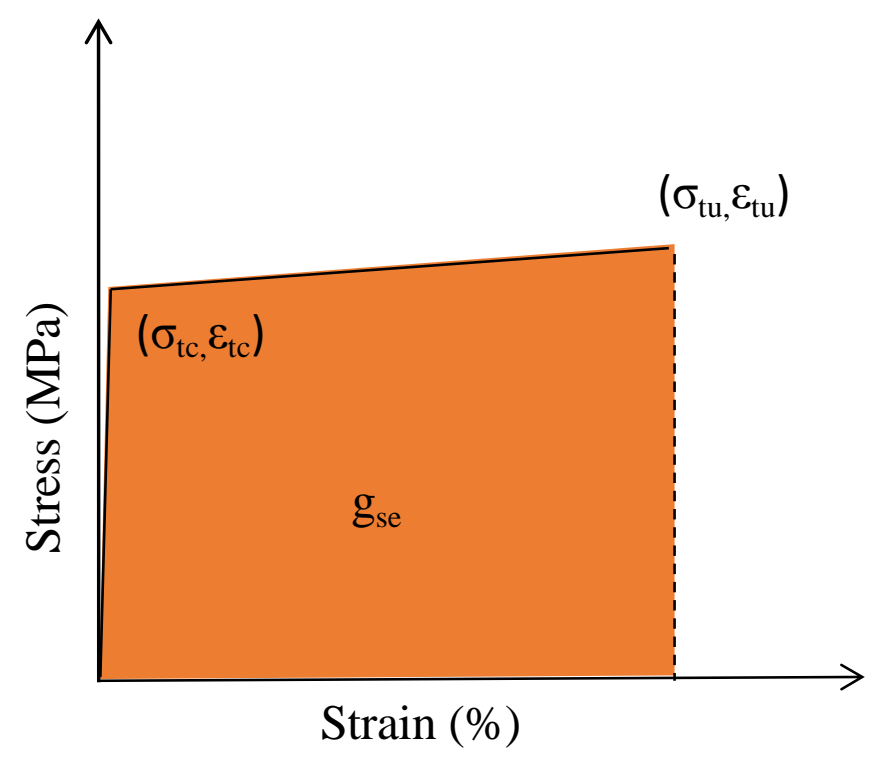

Figure 8. Modeled tensile stress-strain curve and critical parameters.

Figure 10 shows the crack pattern of the HUHP-ECCs tensile specimen. With the increase of PE fiber, the HUHP-ECCs' multi-crack phenomenon appeared obvious. HUHP-ECC-2.0-0 was saturated with micro cracks before the local failure of final crack, while HUHP-ECC-0-2.0 only triggered one main crack and then the steel fiber was pulled out from the specimen. The $L_{f} / d_{f}$ of PE fiber is much larger than that of steel fiber, so it can be seen that the number of cracks is significantly determined by the PE fiber volume. Figure 11 compares the average crack width of the HUHP-ECC specimen. Notice that the increase of steel fiber reduced the crack width of the HUHP-ECC. The average crack width increased from $80 \mu \mathrm{m}$ of HUHP-ECC-0-2.0 to $235 \mu \mathrm{m}$ of HUHP-ECC-2.0-0. The interfacial bond stress between steel fiber and matrix is higher than that between PE fiber and matrix, so the steel fiber can be seen as having more significant effects on the restraint of crack width development, which results in the improvement of crack width control ability of HUHP-ECCs with increasing volume of steel fiber. 
ST (\%)

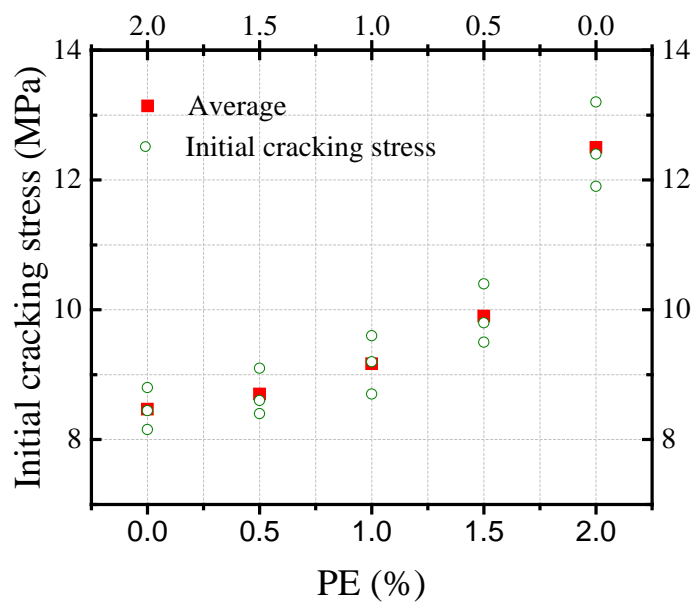

(a)

ST (\%)

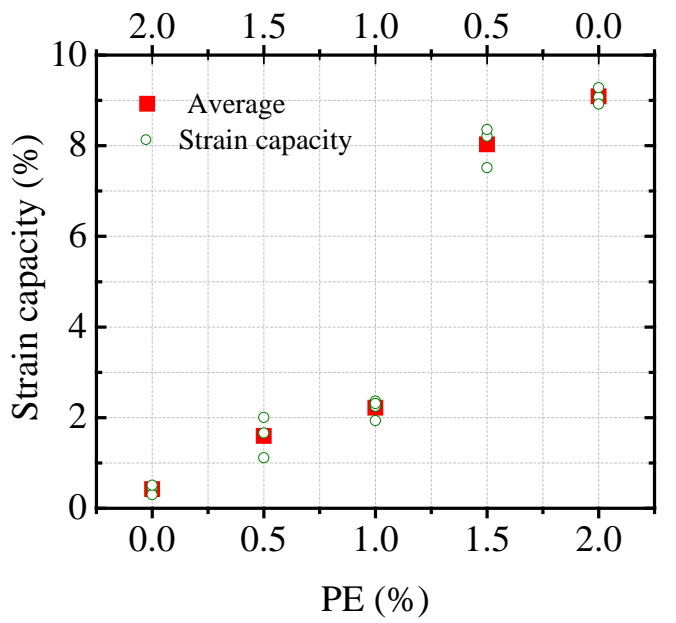

(c)

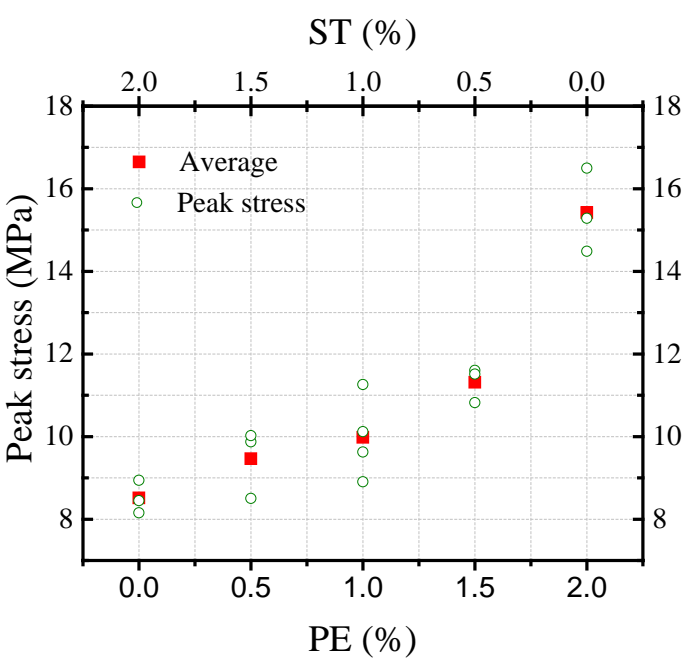

(b)

ST (\%)

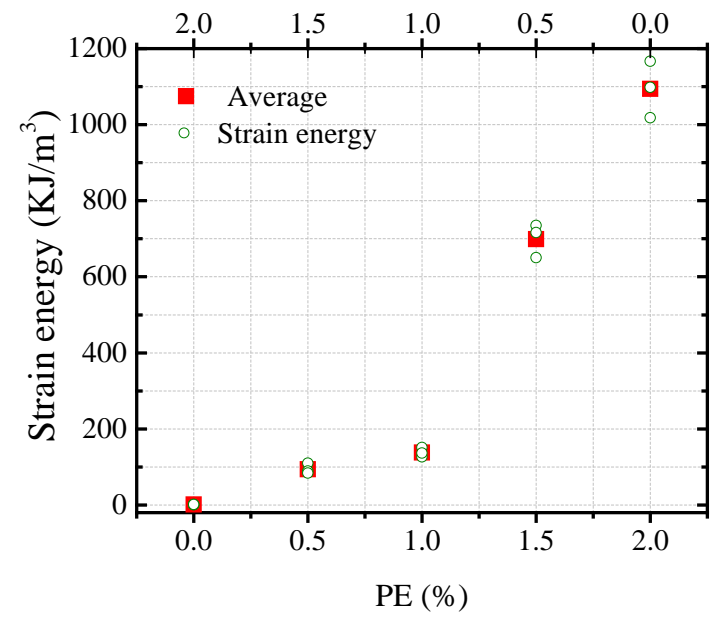

(d)

Figure 9. Tensile parameters of HUHP-ECCs. (a) Initial cracking stress; (b) Tensile strength; (c) Tensile strain capacity; (d) Strain energy.
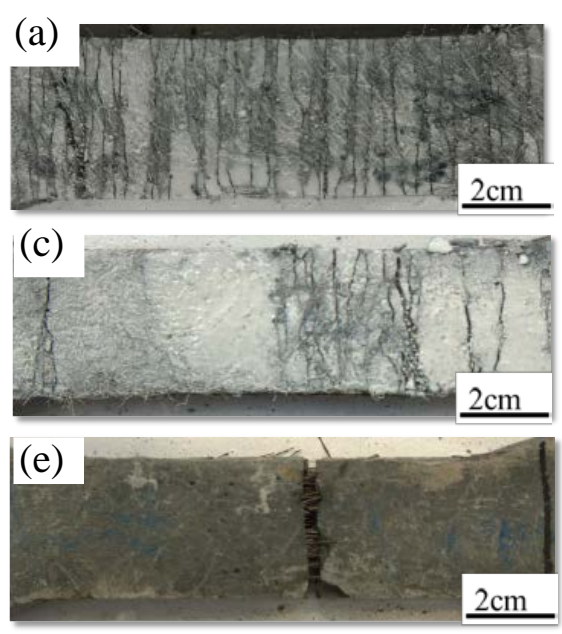

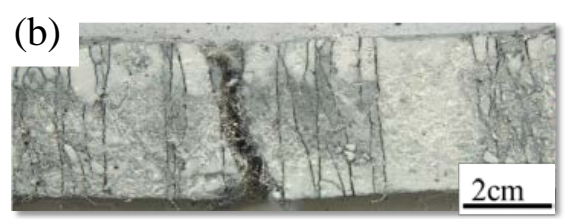

(d)

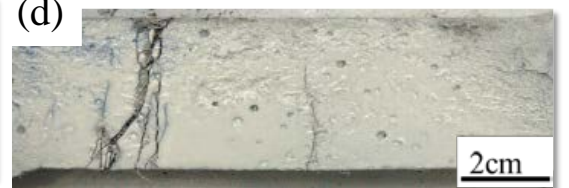

Figure 10. Multiple cracking behavior of different volume fractions of PE and ST fibers. (a) HUHP-2.0-0; (b) HUHP-1.5-0.5; (c) HUHP-1.0-1.0; (d) HUHP-0.5-1.5; (e) HUHP-0-2.0. 


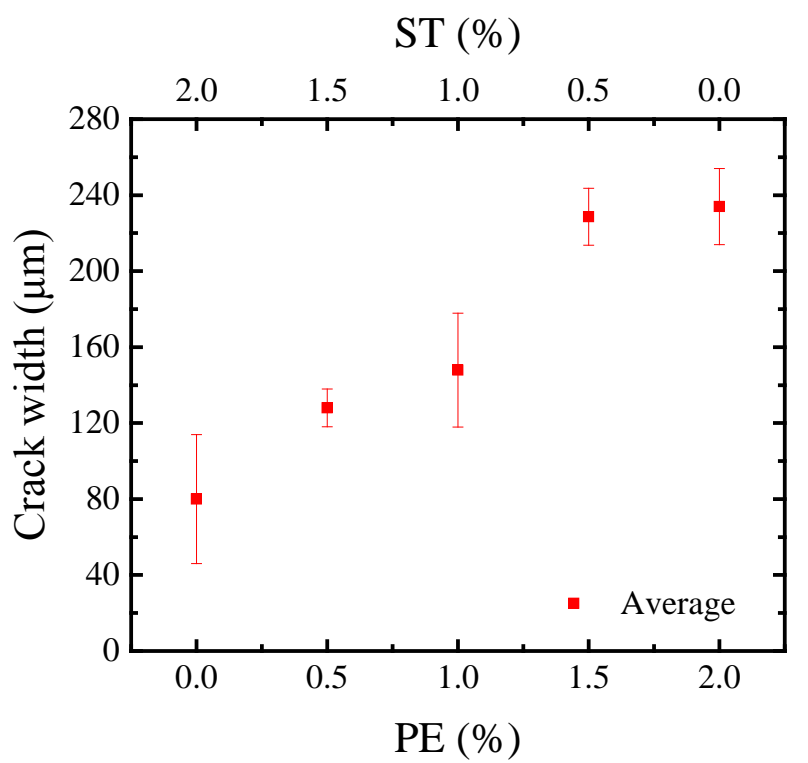

Figure 11. Average crack width of different volume fractions of PE and ST fibers.

\subsection{Flexural Properties}

Figure 12 shows the flexural stress-deflection curves of HUHP-ECCs under four-point bending. All the mixtures show flexural-hardening behavior accompanied by multiple cracks, and the deformation capacity and flexural stress increased significantly with the increase of PE fiber content as shown in Figure $12 \mathrm{~d}$. The average bending strength increased from 16.5 MPa at UHP-ECC-0-2.0 to $30.3 \mathrm{MPa}$ at UHP-ECC-2.0-0 with an increase of $88 \%$, and the deflection/span ratio corresponding to the peak stress increased from 1/200 of UHP-ECC-0-2.0 to 1/66 of UHP-ECC-2.0-0.

The crack distribution at the bottom surface of the HUHP-ECC specimen after failure is shown in Figure 13. The flexural cracks normally appeared in the pure bending zone and localized at the failure stage. The crack number increased gradually with the increasing amount of PE fiber and the distribution was more uniform.

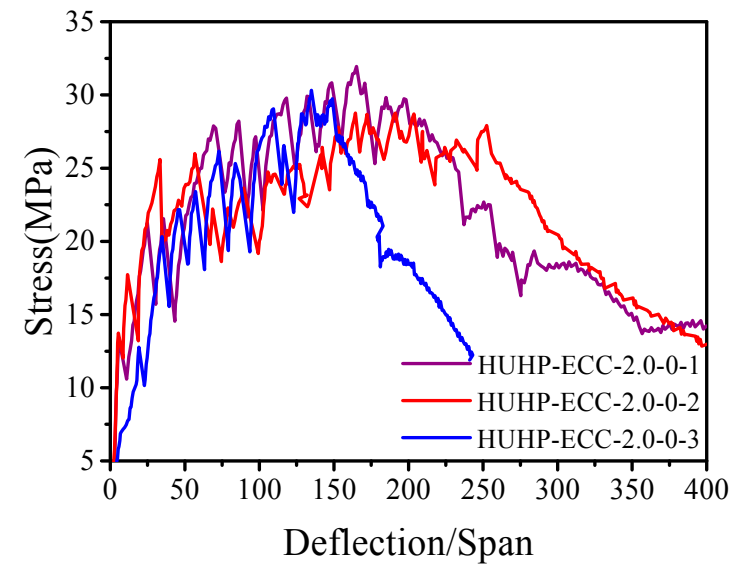

(a)

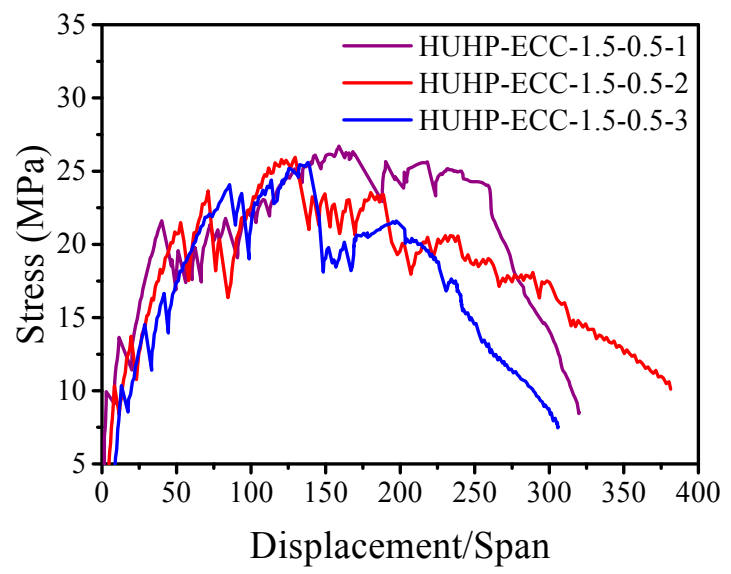

(b)

Figure 12. Cont. 


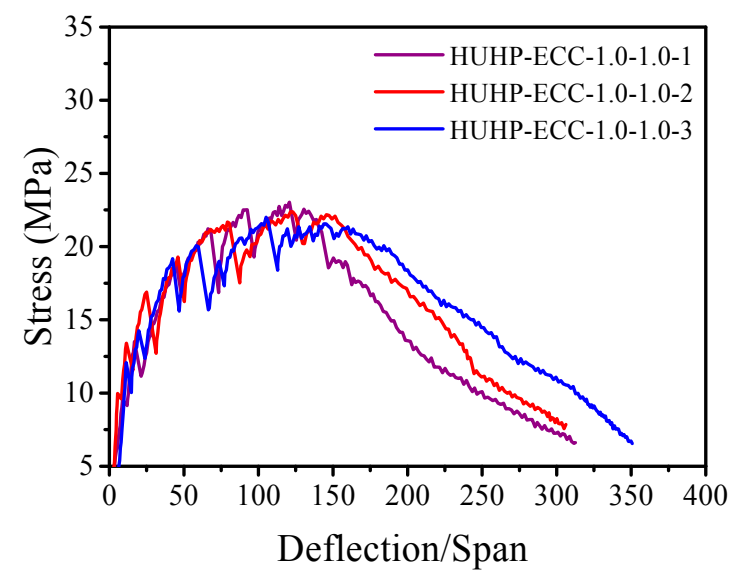

(c)

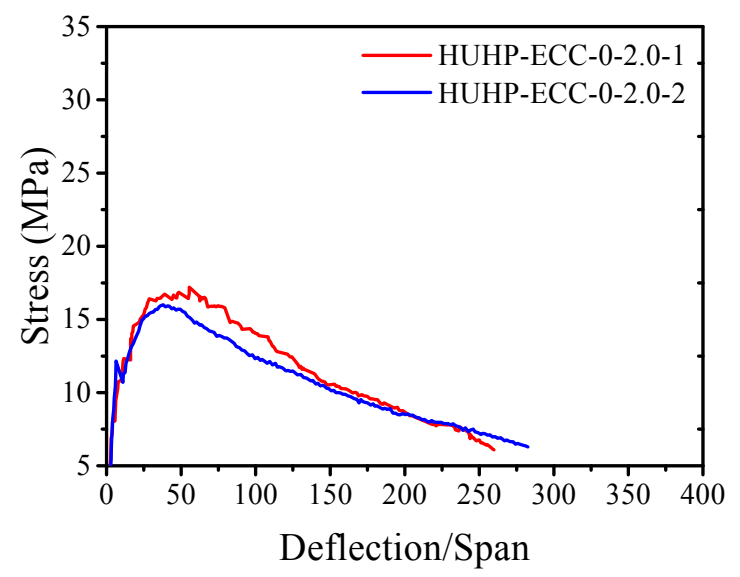

(e)

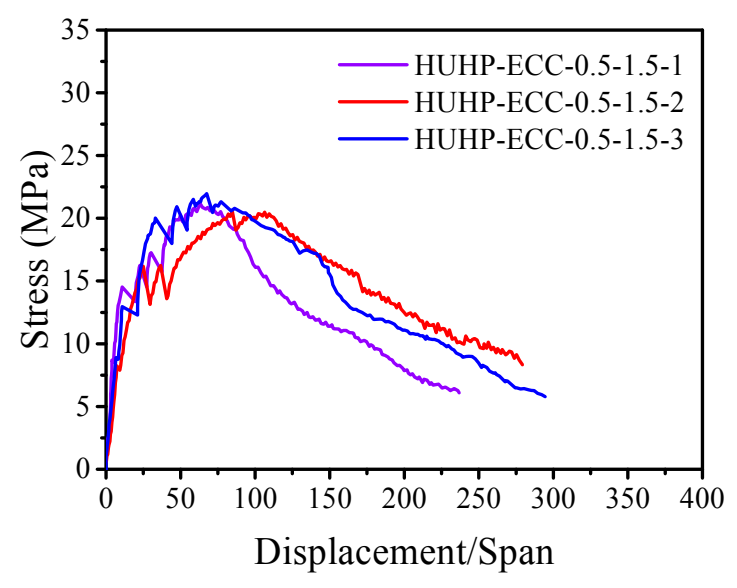

(d)

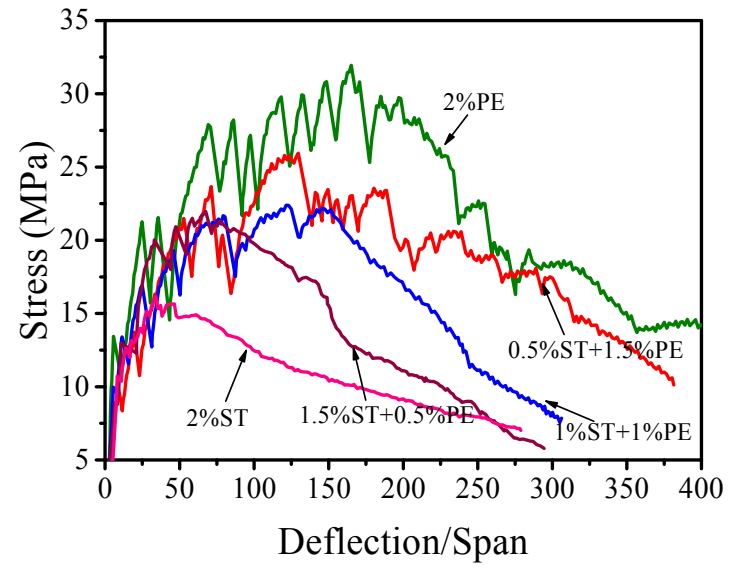

(f)

Figure 12. Stress versus displacement curves of HUHP-ECCs. (a) HUHP-ECC-2.0-0; (b) HUHP-ECC1.5-0.5; (c) HUHP-ECC-1.0-1.0; (d) HUHP-ECC-0.5-1.5; (e) HUHP-ECC-0-2.0; (f) Typical stress versus displacement curves.
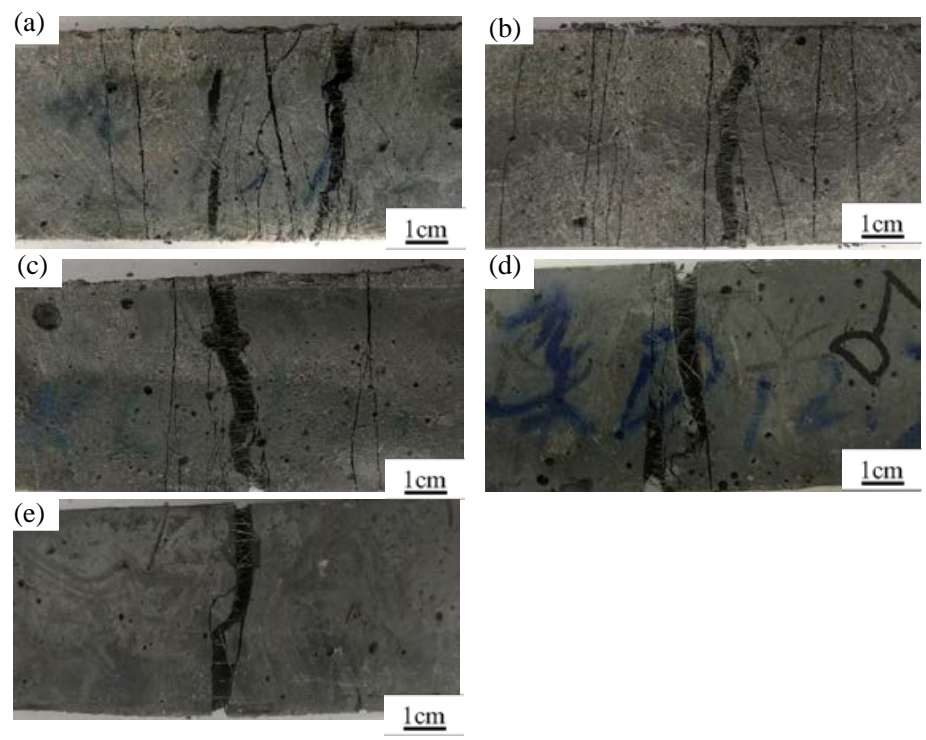

Figure 13. Multiple cracking of HUHP-ECCs. (a) HUHP-2.0-0; (b) HUHP-1.5-0.5; (c) HUHP-1.0-1.0; (d) HUHP-0.5-1.5; (e) HUHP-0-2.0. 


\subsection{Compressive Properties}

The compressive strength of HUHP-ECC was obtained by loading the cube specimens of $40 \times 40 \times 40 \mathrm{~mm}^{3}$ up to failure at a loading rate of $2 \mathrm{kN} / \mathrm{s}$. At least four cube specimens were used for each mixture and the average value was calculated. As shown in Figure 14, the average compressive strength decreased with the increasing amount of PE fiber. In other words, the addition of ST fiber increased the compressive strength of HUHP-ECCs. The compressive strength increased from 99.5 MPa of HUHP-ECC-2.0-0 with 0\% ST fiber to 110.6 MPa of HUHP-ECC-1.5-0.5 with 0.5\% ST fiber and to $135.5 \mathrm{MPa}$ of HUHP-ECC-0.5-1.5 with 1.5\% ST fiber. The compressive strength of HUHP-ECCs with mono $2 \%$ ST fiber showed the highest value of $150.5 \mathrm{MPa}$. The ST fiber had a significantly positive effect on the compressive strength due to the different lateral elastic moduli of these two fibers. Higher PE fiber quantities disturb the density of the matrix and induce more pores, which reduce compressive strength [44].

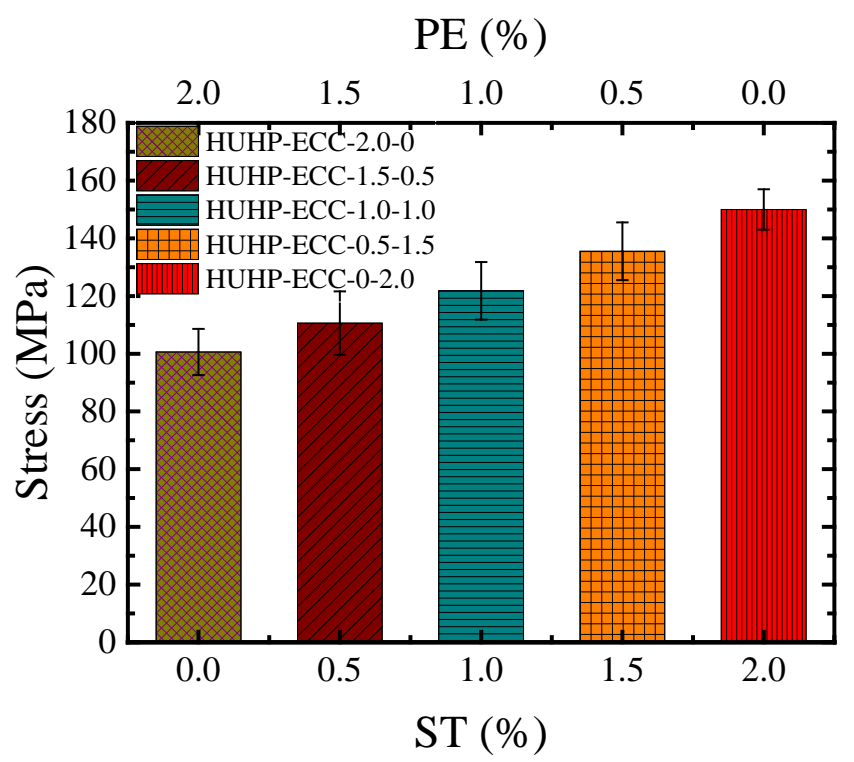

Figure 14. Comparison of compressive strengths of different volume fractions of PE and ST fibers.

\subsection{Interpretation of High Ductility in HUHP-ECC}

In this study, the classic pseudo strain-hardening (PSH) performance index was also calculated to explain the ductility of HUHP-ECC. According to micromechanics [45], the pseudo-strain hardening behavior of ECC is closely related to the crack tip toughness $J_{\text {tip }}$ and the fiber bridging complementary energy $J_{\mathrm{b}}{ }^{\prime}$. In summary, a relatively higher $J_{\mathrm{b}}{ }^{\prime}$ to a lower $J_{\text {tip }}$ promotes flat crack propagation and leading to more cracks. Therefore, researchers calculated the ratio $J_{\mathrm{b}}{ }^{\prime} / J_{\text {tip }}$ which was suggested by Kanda and $\mathrm{Li}$ [45] as a pseudo strain-hardening (PSH) performance index for quantifying the robustness of tensile ductility in ECC (Equation (3)). Figure 15 illustrates the bridging stress $\sigma$ versus crack opening $\delta$ curve, and $J_{\text {tip }}$ and $J_{\mathrm{b}}{ }^{\prime}$, can be calculated by Equations (1)-(3) $[2,46]$, where $E_{\mathrm{m}}$ is the elastic modulus obtained from the uniaxial tension test and the fracture toughness $K_{\mathrm{m}} ; \sigma_{s s}$ and $\delta_{s s}$ represent the fracture stress of matrix and the corresponding crack opening displacement, respectively.

$$
\begin{gathered}
J_{\text {tip }} \leq \sigma_{b} \delta_{b}-\int_{0}^{\sigma_{b}} \sigma(\delta) d \delta \equiv J_{b}^{\prime} \\
J_{\text {tip }}=K_{\mathrm{m}}^{2} / E_{m} \\
P S H=J_{b}^{\prime} / J_{\text {tip }}
\end{gathered}
$$


where $\sigma_{b}$ and $\delta_{b}$ are the fiber bridging stress and the corresponding crack opening displacement, respectively. Equation (3) shows the final ratio based on (1) and (2). The fracture toughness $K_{\mathrm{m}}$ can be derived according to Equations (4)-(6) [47] based on the three-point bending test as shown in Figure 4.

$$
K_{\mathrm{m}}=\frac{1.5\left(F_{Q}+\frac{m g}{2} \times 10^{-2}\right) \times 10^{-3} \cdot S \cdot a_{0}^{1 / 2}}{t h^{2}} f(\alpha)
$$

where

$$
f(\alpha)=\frac{1.99-\alpha(1-\alpha)\left(2.15-3.99 \alpha+2.7 \alpha^{2}\right)}{(1+2 \alpha)(1-\alpha)^{3 / 2}}
$$

and

$$
\alpha=\frac{a_{0}}{h}
$$

where $m$ is the mass of specimen; $F_{\mathrm{Q}}$ is the peak load of the three-point bending specimens, $g$ is the gravitational acceleration; $S$ is span of the three-point beam; $a_{0}$ is preexisting internal flaw size; $t$ and $h$ are the width and height of the three-point beam. $F_{\mathrm{Q}}, m$ and $E_{m}$ are obtained by the aforementioned three-point bending test and the results are listed in Table 5, as well as the calculated $K_{\mathrm{m}}$ and the crack tip toughness $J_{\text {tip. }}$.

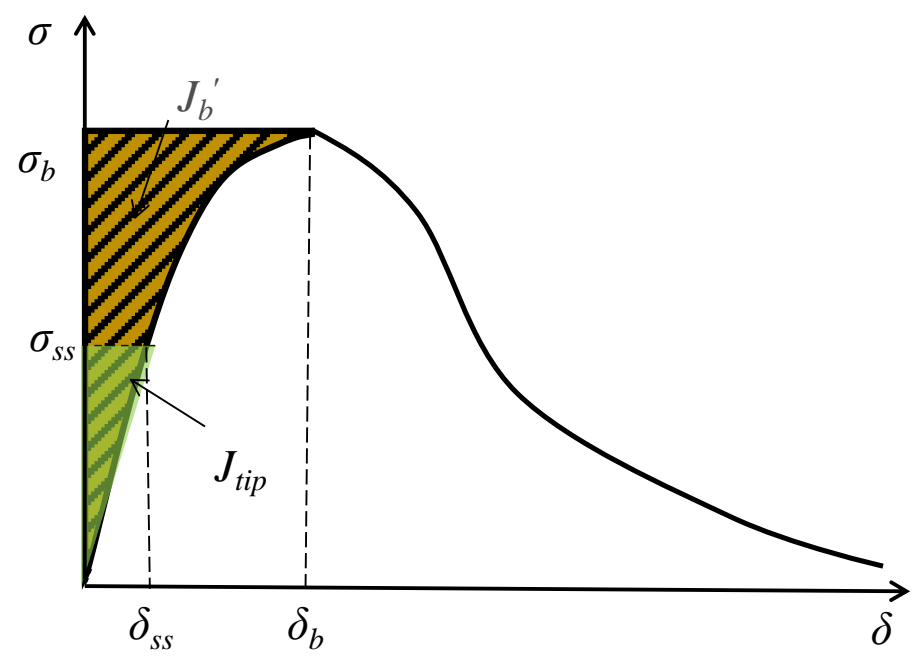

Figure 15. Typical $\sigma-\delta$ curve for strain-hardening composite.

Table 5. Fracture toughness of HUHP-ECC.

\begin{tabular}{cccccc}
\hline Specimen & $E_{\boldsymbol{m}}(\mathbf{G P a})$ & $\mathbf{m} \mathbf{( k g})$ & $F_{\mathbf{Q}}(\mathbf{k N})$ & $K_{\mathbf{m}}\left(\mathbf{M P a ~ \mathbf { m } ^ { \mathbf { 1 } \mathbf { 2 } } )}\right.$ & $J_{\mathrm{tip}}\left(\mathbf{J}_{\mathbf{m}} \mathbf{m}^{\mathbf{2}}\right)$ \\
\hline Matrix of HUHP-ECC & 35.9 & 0.586 & 1.6 & 0.973 & 26.6 \\
S.D. & 0.12 & 0.21 & 0.08 & 0.15 & 0.26 \\
\hline
\end{tabular}

In Equation (1), the fiber bridging complementary energy $J_{\mathrm{b}}{ }^{\prime}$ depends on the relationship curve between the fiber bridging stress $\left(\sigma_{\mathrm{b}}\right)$ and the crack opening displacement $\left(\delta_{\mathrm{b}}\right)$ of HUHP-ECCs, which can be obtained by the single crack tensile test as shown in Figure 5 . The results are shown in Figure 16 , from which $J_{\mathrm{b}}{ }^{\prime}$ is calculated. Figure $16 \mathrm{~d}$ shows that both $\sigma_{\mathrm{b}}$ and $\delta_{\mathrm{b}}$ increased with the volume fraction of PE fiber, which led a higher value of $J_{\mathrm{b}}{ }^{\prime}$ for PE fiber incorporated mixtures. The higher $L_{\mathrm{f}} / d_{\mathrm{f}}$ of PE fiber helped to increase the bridging stress, while the lower bond strength between the PE fiber and matrix increased the crack opening displacement. The specific values of peak bridging stress $\sigma_{\mathrm{b}}$ and corresponding crack opening displacement $\delta_{\mathrm{b}}$ are summarized in Table 6 based on which $J_{\mathrm{b}}{ }^{\prime}$ and PSH are calculated and shown in Table 7. 


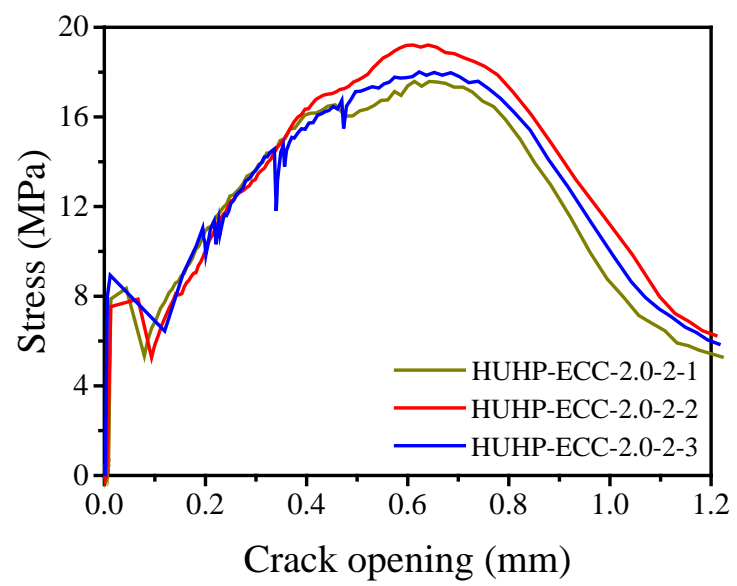

(a)

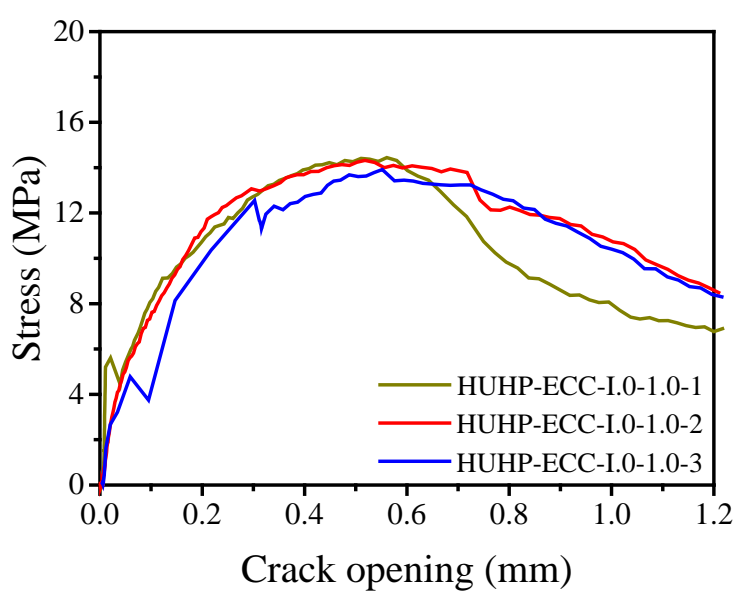

(c)

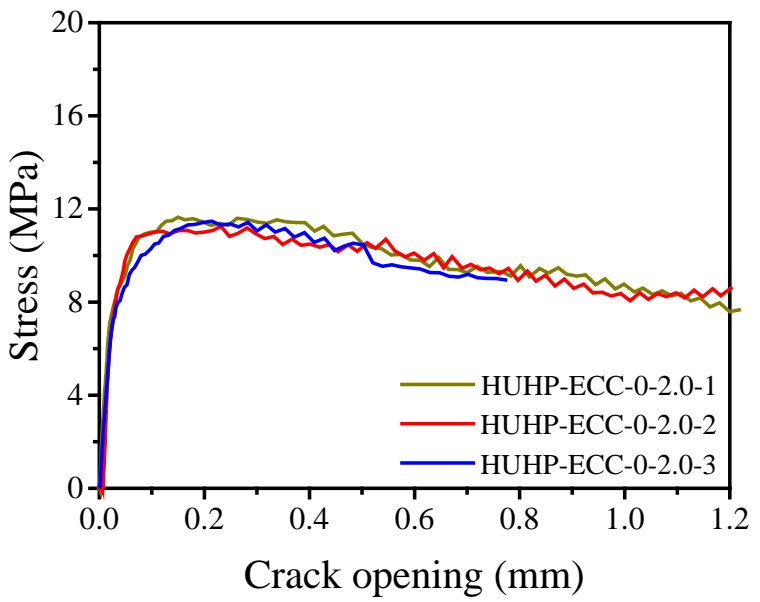

(e)

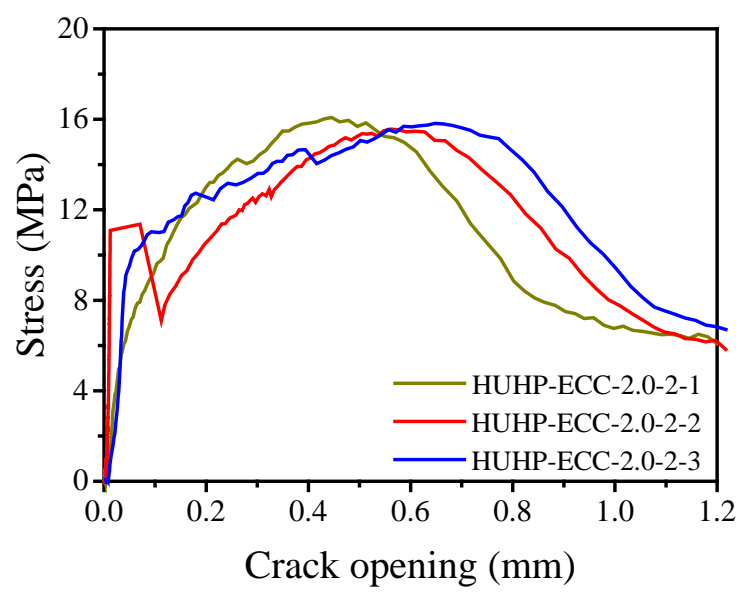

(b)

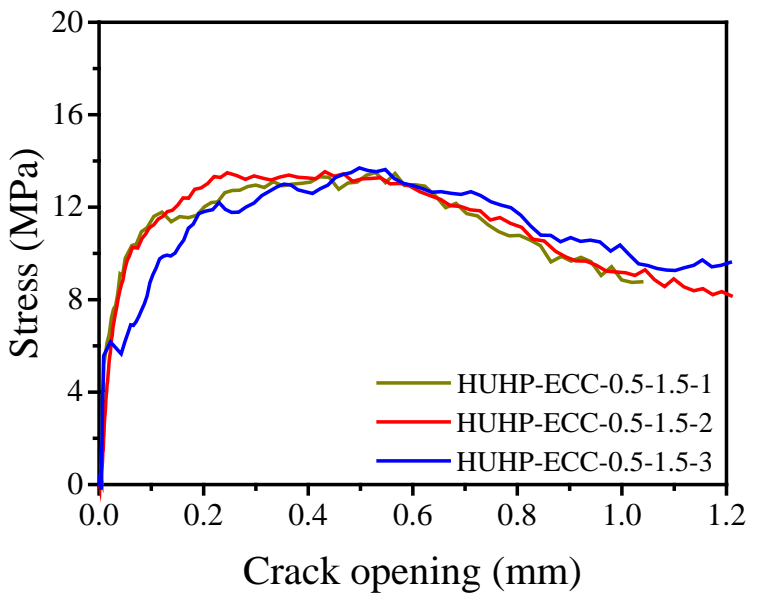

(d)

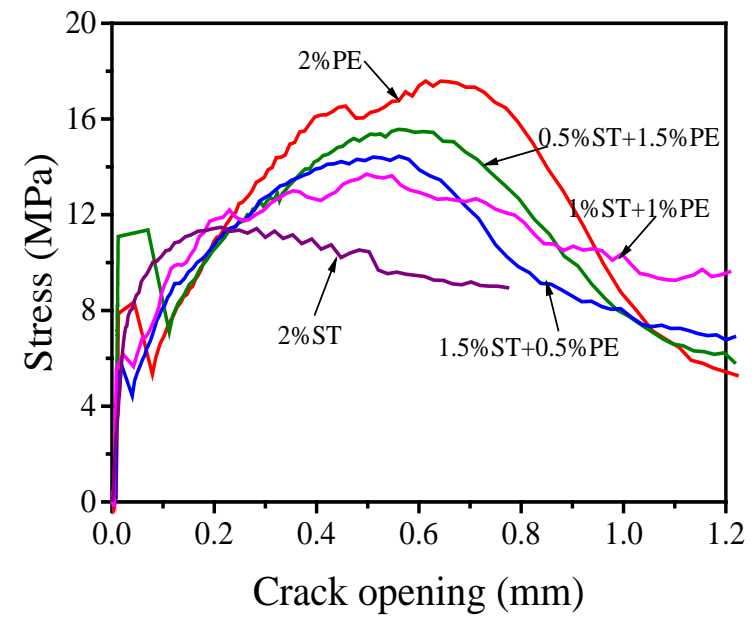

(f)

Figure 16. Bridging stress-crack opening displacement relationships. (a) Stress-crack opening curves of HUHP-ECC-2.0-0; (b) Stress-crack opening curves of HUHP-ECC-1.5-0.5; (c) Stress-crack opening curves of HUHP-ECC-1.0-1.0; (d) Stress-crack opening curves of HUHP-ECC-0.5-1.5; (e) Stress-crack opening curves of HUHP-ECC-0-2.0; (f) Stress-crack opening of different volume fractions of PE and ST fibers. 
Table 6. Results of single-crack tension tests.

\begin{tabular}{|c|c|c|c|c|c|c|c|c|c|c|}
\hline \multirow{2}{*}{ Specimen } & \multicolumn{2}{|c|}{$\begin{array}{c}\text { HUHP-ECC } \\
-2.0-0\end{array}$} & \multicolumn{2}{|c|}{$\begin{array}{c}\text { HUHP-ECC } \\
-1.5-0.5\end{array}$} & \multicolumn{2}{|c|}{$\begin{array}{c}\text { HUHP-ECC } \\
\mathbf{- 1 . 0 - 1 . 0}\end{array}$} & \multicolumn{2}{|c|}{$\begin{array}{c}\text { HUHP-ECC } \\
-\mathbf{0 . 5}-1.5\end{array}$} & \multicolumn{2}{|c|}{$\begin{array}{c}\text { HUHP-ECC } \\
-0-2.0\end{array}$} \\
\hline & $\begin{array}{c}\sigma_{\mathrm{b}} \\
(\mathrm{MPa})\end{array}$ & $\begin{array}{c}\delta_{\mathrm{b}} \\
(\mathrm{mm})\end{array}$ & $\begin{array}{c}\sigma_{\mathrm{b}} \\
(\mathrm{MPa})\end{array}$ & $\begin{array}{c}\delta_{\mathrm{b}} \\
(\mathrm{mm})\end{array}$ & $\begin{array}{c}\sigma_{\mathrm{b}} \\
(\mathrm{MPa})\end{array}$ & $\begin{array}{c}\delta_{\mathrm{b}} \\
(\mathrm{mm})\end{array}$ & $\begin{array}{c}\sigma_{\mathrm{b}} \\
(\mathrm{MPa})\end{array}$ & $\begin{array}{c}\delta_{\mathrm{b}} \\
(\mathrm{mm})\end{array}$ & $\begin{array}{c}\sigma_{\mathrm{b}} \\
(\mathrm{MPa})\end{array}$ & $\begin{array}{c}\delta_{\mathrm{b}} \\
(\mathrm{mm})\end{array}$ \\
\hline Average & 17.33 & 0.642 & 14.81 & 0.551 & 14.44 & 0.492 & 12.53 & 0.452 & 12.43 & 0.224 \\
\hline S.D. & 0.22 & 0.36 & 0.04 & 0.75 & 1.47 & 2.46 & 0.76 & 1.34 & 2.34 & 0.67 \\
\hline
\end{tabular}

Table 7 shows that the fiber bridging complementary energy $J_{\mathrm{b}}{ }^{\prime}$ increased significantly from $41 \mathrm{~J} / \mathrm{m}^{2}$ to $3000 \mathrm{~J} / \mathrm{m}^{2}$ when the PE fiber volume increased from $0 \%$ of HUPH-ECC-0-2.0 to $2 \%$ of HUPH-ECC-2.0-0. The PSH values also increased significantly with the volume fraction of PE fiber increasing from 1.8 at HUHP-ECC-2.0-0 to 112.6 at HUHP-ECC-0-2.0, which explains the increase of strain capacity of HUHP-ECCs with the higher PE fiber volume. As indicated in previous studies, the PSH should be larger than 3 to ensure a strain-hardening behavior [48]. The calculated values of PSH could well explain the tension-softening behavior of HUHP-ECC-0-2.0 and the strain-hardening phenomenon of HUHP-ECC-0.5-1.5. Therefore, high ductility and high strength HUHP-ECC can be designed by incorporating the proper proportion of ST and PE fiber volumes to yield a suitable $\mathrm{PSH}$ value.

Table 7. Results of pseudo strain-hardening (PSH).

\begin{tabular}{cccccc}
\hline Specimens & $\begin{array}{c}\text { HUHP-ECC- } \\
\text { 2.0-0 }\end{array}$ & $\begin{array}{c}\text { HUHP-ECC- } \\
\mathbf{1 . 5 - 0 . 5}\end{array}$ & $\begin{array}{c}\text { HUHP-ECC- } \\
\mathbf{1 . 0 - 1 . 0}\end{array}$ & $\begin{array}{c}\text { HUHP-ECC- } \\
\mathbf{0 . 5 - 1 . 5}\end{array}$ & $\begin{array}{c}\text { HUHP-ECC- } \\
\mathbf{0 - 2 . 0}\end{array}$ \\
\hline $\boldsymbol{J}_{\mathbf{b}}{ }^{\prime}\left(\boldsymbol{J} / \mathbf{m}^{\mathbf{2}}\right)$ & 3000 & 1938 & 1520 & 500 & 47 \\
$\mathbf{P S H}$ & 112.6 & 72.7 & 57.1 & 18.8 & 1.8 \\
\hline
\end{tabular}

\subsection{Microstructure of HUHP-ECC}

The test results presented thus far indicate that HUHP-ECC reinforced with different amounts of PE and ST fibers shows distinct mechanical properties, which is closely related to the failure mode of the fiber. In this section, the PE and ST fiber failure modes in the fractured section after the tensile test illustrated in Figure 2 were investigated by the Quanta TM250 ESEM (FEI Company, Hillsboro, OR, USA). The morphology of tested specimens was prepared by taking small pieces from the dogbone specimens on the fractured surface. Figure 17 shows the images of PE and ST fiber failure modes in HUHP-ECC-2.0-0 specimen and HUHP-ECC-1.0-1.0 specimen Day 28. For specimen HUHP-ECC-2.0-0 reinforced with mono $P E$ fiber, most of the PE fibers ruptured with a coinciding pull-out failure from the matrix as shown in Figure 17a. The lateral surface of the PE fiber in the HUHP-ECC-2.0-0 specimen was grooved severely on the surface or even fractured during the pull-out process as can be seen in Figure 17b. However, for specimen HUHP-ECC-1.0-1.0 reinforced with PE and ST fibers, most of the PE fibers were pulled out from the matrix with a neat end as shown in Figure 17c,d. The steel fiber surface was smooth and slightly stuck to the matrix particles; moreover, it is obvious that the diameter of ST fiber was much larger than that of the PE fiber (Figure 17c). 


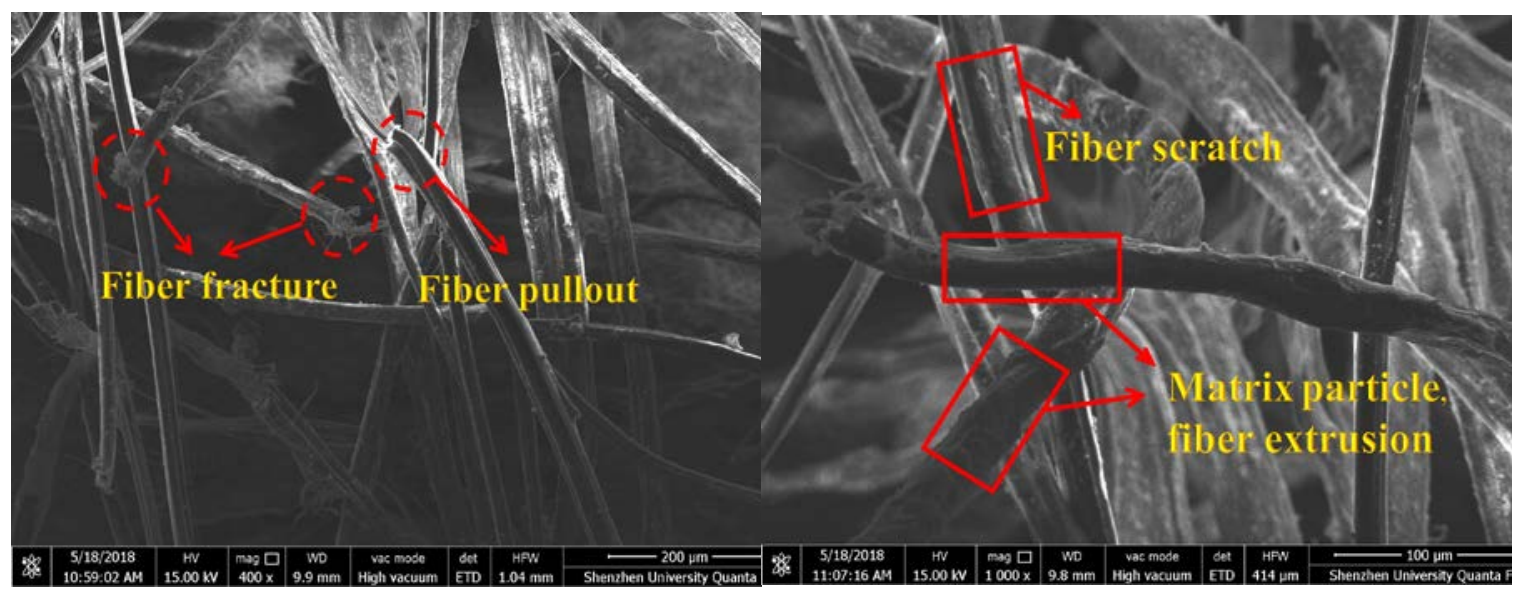

(a)

(b)

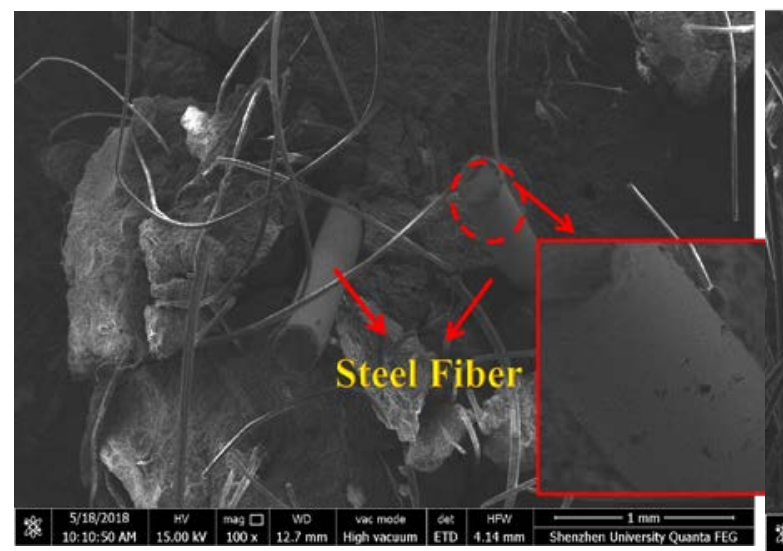

(c)
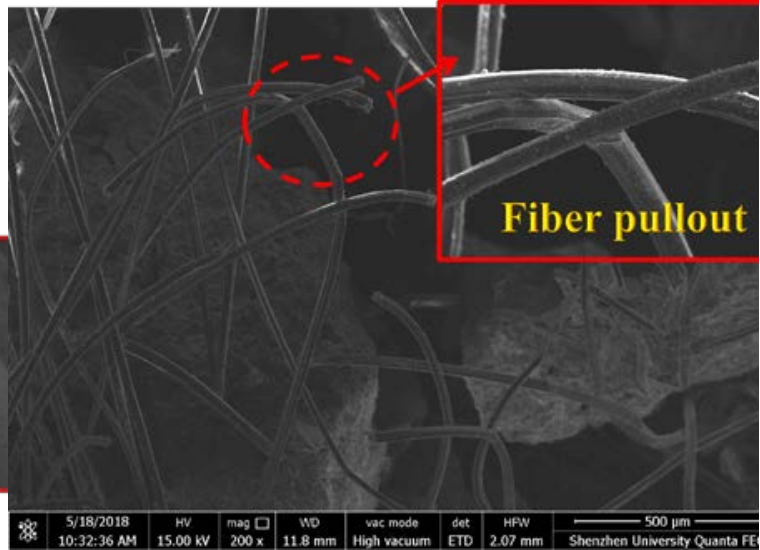

(d)

Figure 17. Environmental scanning electron microscopy (ESEM) images of PE and ST fiber and the fiber/matrix interface of HUHP-ECCs. (a) Fiber pull off surface (HUHP-ECC-2.0-0); (b) Fiber surface damage (HUHP-ECC-2.0-0); (c) Steel fiber pull out surface (HUHP-ECC-1.0-1.0); (d) Fiber pull out surface (HUHP-ECC-1.0-1.0).

\section{Conclusions}

A hybrid fiber reinforced ultra-high performance engineered cementitious composite (HUHP-ECC) was developed in the research presented herein. Different mechanical properties, which include the compressive, tensile, and flexural properties are obtained by adjusting the amounts of the fibers. The fiber combination effects on the fluidity of HUHP-ECC were also studied. The pseudo strain-hardening (PSH) values for all the HUHP-ECC mixtures were calculated to explain the ductility of HUHP-ECC. Finally, the morphology of PE and ST fiber at the fracture surface was observed by an environmental scanning electron microscope. The following conclusions could be drawn.

1. All the HUHP-ECCs demonstrated the strain-hardening phenomenon in tension except the HUHP-ECC-0-2.0 with mono ST fiber. The tensile properties, including both strength and ductility, increased with the amount of PE fiber. The tensile strain capacity of HUHP-ECC-0.5-1.5 with the $0.5 \%$ PE fiber reached $1.5 \%$, which was much higher than the value of UHPC. The strain capacity reached $9.1 \%$ and $8.1 \%$ for HUHP-ECC-2.0-0 and HUHP-ECC-1.5-0.5, respectively. The tensile strength increased from $8.5 \mathrm{MPa}$ to $15.5 \mathrm{MPa}$ with an increase of $182 \%$. 
2. All the HUHP-ECCs demonstrated the strain-hardening phenomenon in flexure and the flexural strength also increased with the amount of PE fiber. While the compressive strength had the opposite tendency with the increasing PE fiber volume fraction. The addition of PE fiber imposed a negative influence on the compressive strength due to the lower lateral elastic modulus of PE fiber. Additionally, the higher quantities of PE fiber disturbed the density of the matrix and induced more pores that would reduce the compressive strength. The compressive strength of HUHP-ECC-2.0-0 and HUHP-ECC-0-2.0 were 99.5 and 150.5 MPa.

3. The fluidity of HUHP-ECC was adjustable by different combinations of ST and PE fibers. The fluidity of the HUHP-ECC increased from $140 \mathrm{~mm}$ with mono $2 \%$ PE fiber to $330 \mathrm{~mm}$ with mono $2 \%$ ST fiber. The hybrid fiber-reinforced UHP-ECCs had a spread fluidity, which ranged from $170 \mathrm{~mm}$ to $270 \mathrm{~mm}$, with the combination of proper mechanical properties (tensile, flexural, and compressive properties) and fluidity, which may have a wider application in practical engineering.

4. The fracture toughness of the matrix and the single-crack tension test of HUHP-ECCs were conducted to obtain the PSH values to explain the tensile strain-hardening phenomenon of HUHP-ECCs. Both the peak bridging stress and the corresponding crack opening displacement increased with the volume fraction of PE fiber, which led a higher value of $J_{\mathrm{b}}$ ' for PE fiber incorporated mixtures. The higher $L_{\mathrm{f}} / d_{\mathrm{f}}$ of PE fiber helped to increase the bridging stress, while the lower bond strength between the PE fiber and matrix increased the crack opening displacement. The morphology of the samples was studied by ESEM analysis. Without ST fiber, most of the PE fibers ruptured along with the pull-out failure from the matrix; however, with the introduction of ST fiber, the failure mode of the PE fiber mainly changed to pull out failure. The lateral surface of PE fiber in HUHP-ECC-2.0-0 specimen was grooved severely on the surface. Conversely, the steel fiber surface was smooth and slightly stuck to matrix particles, making it obvious that the diameter of ST fiber was much larger than that of the PE fiber.

Author Contributions: Yingwu Zhou conceived and designed the experimental work; Bin Xi conducted the experiments and analyzed the data; Lili Sui provided constructive suggestions about the work; Kequan Yu given great constructive comments on the work and performed editing, Feng Xing proposed the original idea and analyzed the results; and all the authors wrote the paper.

Funding: The work described in this paper was financially supported by the National Natural Science Foundation of China (Grants No. 51622808, 51778371, 51578337, and 51378338), and the Shenzhen Basic Research Project (Grant No. GJHZ20170314105503899), for which the authors are grateful.

Conflicts of Interest: The authors declare no conflict of interest.

\section{References}

1. Li, V.C. On engineered cementitious composites (ECC): A review of the material and its applications. J. Adv. Concr. Technol. 2003, 1, 215-230. [CrossRef]

2. Li, V.C.; Leung, C.K.Y. Steady-state and multiple cracking of short random fiber composites. J. Eng. Mech. 1992, 118, 2246-2264. [CrossRef]

3. Li, V.C.; Wang, S.; Wu, C. Tensile strain-hardening behavior of polyvinyl alcohol engineered cementitious composite (PVA-ECC). ACI. Mater. J. 2001, 98, 483-492.

4. Herbert, E.N.; Li, V.C. Self-Healing of Microcracks in Engineered Cementitious Composites (ECC) Under a Natural Environment. Materials 2013, 6, 2831-2845. [CrossRef] [PubMed]

5. Richard, P.; Cheyrezy, M. Composition of reactive powder concretes. Cem. Concr. Res. 1995, 25, $1501-1511$. [CrossRef]

6. Sui, L.; Luo, M.; Yu, K.; Xing, F.; Li, P.; Zhou, Y.; Chen, C. Effect of engineered cementitious composite on the bond behavior between fiber-reinforced polymer and concrete. Compos. Struct. 2018, 184, 775-788. [CrossRef]

7. Li, V.C. Tailoring ECC for special attributes: A review. Int. J. Concr. Struct. Mater. 2012, 6, 135-144. [CrossRef]

8. Yu, K.Q.; Dai, J.G.; Lu, Z.D.; Poon, C.S. Rate-dependent tensile properties of ultra-high performance engineered cementitious composites (UHP-ECC). Cem. Concr. Compos. 2018, 93, 218-234. [CrossRef] 
9. Sui, L.L.; Zhong, Q.L.; Yu, K.Q.; Xing, F.; Li, P.; Zhou, Y.W. Flexural Fatigue Properties of Ultra-High Performance Engineered Cementitious Composites (UHP-ECC) Reinforced by Polymer Fibers. Polymers 2018, 10, 892. [CrossRef]

10. Yu, K.Q.; Wang, Y.C.; Yu, J.T.; Xu, S.L. A strain-hardening cementitious composites with the tensile capacity up to 8\%. Constr. Build. Mater. 2017, 137, 410-419. [CrossRef]

11. Yu, K.Q.; Yu, J.T.; Dai, J.G.; Lu, Z.D.; Shah, S.P. Development of ultra-high performance engineered cementitious composites using polyethylene (PE) fibers. Constr. Build. Mater. 2018, 158, 217-227. [CrossRef]

12. Ding, Y.; Yu, J.T.; Yu, K.Q.; Xu, S.L. Basic mechanical properties of ultra-high ductility cementitious composites: From $40 \mathrm{MPa}$ to $120 \mathrm{MPa}$. Compos. Struct. 2018, 185, 634-645. [CrossRef]

13. Yu, K.Q.; Yu, J.T.; Dai, J.G.; Lu, Z.D.; Shah, S.P. Structural behaviors of ultra-high performance engineered cementitious composites (UHP-ECC) beams subjected to bending-experimental study. Constr. Build. Mater. 2018, 177, 102-115.

14. Bhat, P.S.; Chang, V.; Li, M. Effect of elevated temperature on strain-hardening engineered cementitious composites. Constr. Build. Mater. 2014, 69, 370-380. [CrossRef]

15. Liu, J.C.; Tan, K.H.; Zhang, D. Multi-response optimization of post-fire performance of strain hardening cementitious composite. Cem. Concr. Compos. 2017, 80, 80-90. [CrossRef]

16. Yu, K.Q.; Dai, J.G.; Lu, Z.D.; Leung, C.K.Y. Mechanical properties of engineered cementitious composites subjected to elevated temperatures. J. Mater. Civ. Eng. 2015, 27, 04014268. [CrossRef]

17. Li, X.; Bao, Y.; Xue, N.; Chen, G. Bond strength of steel bars embedded in high-performance fiber-reinforced cementitious composite before and after exposure to elevated temperature. Fire. Safety. J. 2017, 92, 98-106. [CrossRef]

18. Cheyrezy, M.; Maret, V.; Frouin, L. Microstructural analysis of RPC (reactive powder concrete). Cem. Concr. Res. 1995, 25, 1491-1500. [CrossRef]

19. Reda, M.M.; Shrive, N.G.; Gillott, J.E. Microstructural investigation of innovative UHPC. Cem. Concr. Res. 1999, 29, 323-329. [CrossRef]

20. Graybeal, B.; Davis, M. Cylinder or cube: strength testing of 80 to $200 \mathrm{MPa}$ (11.6 to $29 \mathrm{ksi}$ ) ultra-highperformance fiber-reinforced concrete. Mater. J. 2008, 105, 603-609.

21. Hrynyk, T.D.; Vecchio, F.J. Behavior of steel fiber-reinforced concrete slabs under impact load. ACI. Struct. J. 2014, 111, 1213. [CrossRef]

22. Zheng, W.; Luo, B.; Wang, Y. Compressive and tensile properties of reactive powder concrete with steel fibers at elevated temperatures. Constr. Build. Mater. 2013, 41, 844-851. [CrossRef]

23. Lau, A.; Anson, M. Effect of high temperatures on high performance steel fiber reinforced concrete. Cem. Concr. Res. 2006, 36, 1698-1707. [CrossRef]

24. Wang, R.; Gao, X. Relationship between flowability, entrapped air content and strength of UHPC mixtures containing different dosage of steel fiber. Appl. Sci. 2016, 6, 216. [CrossRef]

25. Lee, M.G.; Huang, Y.S. Fire-damage or freeze-thaw of strengthening concrete using ultra high performance concrete. Adv. Mater. Res. 2009, 79, 2047-2050. [CrossRef]

26. Kang, S.H.; Lee, J.H.; Hong, S.G.; Moon, J. Microstructural investigation of heat-treated ultra-high performance concrete for optimum production. Materials 2017, 10, 1106. [CrossRef] [PubMed]

27. Wille, K.; Kim, D.J.; Naaman, A.E. Strain-hardening UHP-FRC with low fiber contents. Mater. Struct. 2011, 44, 583-598. [CrossRef]

28. Naaman, A.E.; Reinhardt, H.W. Proposed classification of HPFRC composites based on their tensile response. Mater. Struct. 2006, 39, 547-555. [CrossRef]

29. Park, J.-J.; Yoo, D.-Y.; Park, G.-J.; Kim, S.-W. Feasibility of Reducing the Fiber Content in Ultra-HighPerformance Fiber-Reinforced Concrete under Flexure. Materials 2017, 10, 118. [CrossRef] [PubMed]

30. Rossi, P.; Acker, P.; Malier, Y. Effect of steel fibers at two different stages, the material and the structure. Mater. Struct. 1987, 20, 436-439. [CrossRef]

31. Wuest, J.; Denarie, E.; Bruehwiler, E. Model for predicting the UHP-FRC tensile hardening response. In Proceedings of the second international symposium on ultra high performance concrete, Kassel, Germany, 5-7 March 2008; Fehling, E., Schmidt, M., Stúrwald, S., Eds.; Kassel University Publications: Kassel, Germany, 2008; pp. 153-160.

32. Park, S.H.; Kim, D.J.; Ryu, G.S.; Koh, K.T. Tensile behavior of ultra high performance hybrid fiber reinforced concrete. Cem. Concr. Compos. 2012, 34, 172-184. [CrossRef] 
33. Qian, C.X.; Stroeven, P. Development of hybrid polypropylene-steel fibre-reinforced concrete. Cem. Concr. Res. 2000, 30, 63-69. [CrossRef]

34. Ahmed, S.F.U.; Maalej, M.; Paramasivam, P. Flexural responses of hybrid steel-polyethylene fiber reinforced cement composites containing high volume fly ash. Constr. Build. Mater. 2007, 21, 1088-1097. [CrossRef]

35. Zhang, W.; Yin, C.; Ma, F.; Huang, Z. Mechanical Properties and Carbonation Durability of Engineered Cementitious Composites Reinforced by Polypropylene and Hydrophilic Polyvinyl Alcohol Fibers. Materials 2018, 11, 1147. [CrossRef] [PubMed]

36. Chen, B.; Liu, J. Residual strength of hybrid-fiber-reinforced high-strength concrete after exposure to high temperatures. Cem. Concr. Res. 2004, 34, 1065-1069. [CrossRef]

37. Ahmed, S.F.U.; Maalej, M. Tensile strain hardening behaviour of hybrid steel-polyethylene fibre reinforced cementitious composites. Constr. Build. Mater. 2009, 23, 96-106. [CrossRef]

38. Li, V.C. Engineered cementitious composites-a tailored composite through micromechanical modeling. In Fiber Reinforced Concrete: Present and the Future; Banthia, N., Bentur, A., Mufti, A., Eds.; Canadian Society of Civil Engineer s: Montreal, Canada, 1998; pp. 64-97.

39. Wang, S.; Wu, C.; Li, V.C. Interface Tailoring for Strain-Hardening Polyvinyl Alcohol-Engineered Cementitious Composite (PVA-ECC). Mater. J. 2002, 99, 463-472.

40. GB/T2419-2005. Cement Mortar Fluidity Analyzer, the NLD,-3 Cement Mortar Fluidity Tester; Standardization Administration of China: Beijing, China, 2005.

41. JSCE 1-16. Recommendations for Design and Construction of High Performance Fiber Reinforced Cement Composites with Multiple Fine Cracks; Japan Society of Civil Engineers Press: Tokyo, Japan, 2008.

42. CECS 44-8. Standard Test Methods for Fiber Reinforced Concrete; China Engineering and Construction Society Press: Beijing, China, 2009.

43. Rilem, T.C. Determination of the fracture energy of mortar and concrete by means of three-point bend tests on notched beams. Mater. Struct. 1985, 18, 285-290.

44. Graybeal, B.A. Compressive behavior of ultra-high-performance fiber-reinforced concrete. ACI. Mater. J. 2007, 104, 146.

45. Kanda, T.; Li, V.C. New micromechanics design theory for pseudostrain hardening cementitious composite. J. Eng. Mech. 1999, 125, 373-381. [CrossRef]

46. Marshall, D.B.; Cox, B.N. A J-integral method for calculating steady-state matrix cracking stresses in composites. Mech. Mater. 1988, 7, 127-133. [CrossRef]

47. Xu, S.; Reinhardt, H.W. Determination of double-K criterion for crack propagation in quasi-brittle fracture, Part II, Analytical evaluating and practical measuring methods for three-point bending notched beams. Int. J. Fract. 1999, 98, 151-177. [CrossRef]

48. Kanda, T.; Li, V.C. Multiple cracking sequence and saturation in fiber reinforced cementitious composites. Conc. Res. Technol. JCI 1998, 9, 19-33. [CrossRef]

(C) 2018 by the authors. Licensee MDPI, Basel, Switzerland. This article is an open access article distributed under the terms and conditions of the Creative Commons Attribution (CC BY) license (http://creativecommons.org/licenses/by/4.0/). 